\title{
Targeted Business Incentives and the Debt Behavior of Households
}

Wenhua Di and Daniel L Millimet

Federal Reserve Bank of Da llas

Research Department

Working Paper 1602 


\title{
Targeted Business Incentives and the Debt Behavior of Households
}

\author{
Wenhua Di \\ Federal Reserve Bank of Dallas \\ Wenhua.di@dal.frb.org \\ Daniel L. Millimet ${ }^{\diamond}$ \\ Southern Methodist University \\ IZA \\ Federal Reserve Bank of Dallas \\ millimet@mail.smu.edu
}

January 2016

\begin{abstract}
The empirical effects of place-based tax incentive schemes designed to aid low-income communities are unclear. While a growing number of studies find beneficial effects on employment, there is little investigation into other behaviors of households affected by such programs. We analyze the impact of the Texas Enterprise Zone Program on household debt and delinquency. Specifically, we utilize detailed information on all household liabilities, delinquencies, and credit scores from the Federal Reserve Bank of New York Consumer Credit Panel/Equifax, a quarterly longitudinal 5\% random sample of all individuals in the US with a social security number and a credit report. We identify the causal effect of the program by using a sharp regression discontinuity approach that exploits the known institutional rules of the program. We find a modest positive impact on the repayment of retail loans, and the evidence of an increase in the delinquency rates of auto loans, as well as in Chapter 13 bankruptcy filings.
\end{abstract}

Keywords: Enterprise Zones, Debt, Consumer Finance, Regression Discontinuity JEL Classifications: C21, G02, H25, H31

\footnotetext{
*The information, analyses, and conclusions set forth are those of the authors and do not necessarily indicate concurrence by the Board of Governors of the Federal Reserve System, the Federal Reserve Banks, or members of their staffs. The authors are grateful to Matthew Freedman for sharing his data and Sarah Greer for her research assistance. The authors would also like to thank the audience of the research conference: Intent vs. Impact: Evaluating Individual and Community-Based Programs at the Federal Reserve Bank of Dallas for their feedback. ${ }^{\diamond}$ Corresponding author.
} 


\section{Introduction}

Within wealthy countries, such as the US, there exist significant spatial heterogeneity in economic outcomes. In October 2015, Bismarck, North Dakota had the lowest unemployment rate (at 1.8\%) among metropolitan areas; Yuma, Arizona had the highest (at 23.2\%). ${ }^{1}$ Even within a single state, such heterogeneity occurs. For example, across counties in Texas, the unemployment rate in 2014 varied from 1.7\% (McMullen County) to 13.5\% (Starr County). ${ }^{2}$ Kline and Moretti (2013) state that, at any point in time, variation in the unemployment rate across locations is comparable to variation over the business cycle. Moretti (2011) notes that such spatial variation extends beyond the unemployment rate to other outcomes such hourly wages, total factor productivity, and firm innovation.

In response to such heterogeneity, place-based policies have become an increasingly common component of regional economic development programs since the 1970s. The defining characteristic of place-based policies is that they entail transfers of government resources to places, rather than individuals. Ladd (1994) further delineates among government transfer policies by differentiating between "pure place strategies" and "place-based people strategies." The former refers to policies designed to improve specific geographic areas (such as a downtown area) for reasons that may be independent of the well-being of the residents (or for reasons related to the well-being of individuals outside the immediate area of focus). The latter refers to policies designed to improve specific geographic areas for reasons directly related to the wellbeing of the residents (such as neighborhoods with a high concentration of poverty). Both types of place-based policies can be contrasted with people-based policies that transfer government resources to specific individuals regardless of place of residence (Neumark and Simpson 2015).

Place-based policies date back to at least the Great Depression in the US and the creation of the Tennessee Valley Authority. ${ }^{3}$ Since the 1970s, numerous other placed-based policies have come into existence around the globe. Accetturo and de Blasio (2012, p. 15) state that "governments around the globe are now actively engaged in programs to spur local economic development in backward areas." These include US state and federal programs, European Union

\footnotetext{
${ }^{1}$ See Unemployment Rates for Metropolitan Areas, Bureau of Labor Statistics, http://www.bls.gov/web/metro/laummtrk.htm.

${ }^{2}$ See Labor Force Statistics for Texas Counties , Texas Workforce Commission, http://www.txcip.org/tac/census/morecountyinfo.php?MORE=1042.

${ }^{3}$ Kline and Moretti (2014) note that examples go back much further in time as the tax system was used to redistribute resources from the remainder of the Empire to citizens of Rome.
} 
policies, programs in Asia, etc. Kline and Moretti (2014) and Neumark and Simpson (2015) provide an excellent account. However, while the goal of economic policy is often to ensure political stability through greater equity (Accetturo and de Blasio 2012), Busso et al. (2013, p. 897) argue that "economists have traditionally expressed little support" for place-based programs out of fear that "they will generate large distortions in economic behavior." Indeed, Gobillon et al. (2012, p. 881) describes place-based policies as "rather controversial," as does Mayer et al. (2015).

In this paper, we empirically assess the causal effects of a particular place-based policy, the Texas Enterprise Zone Program (TEZP), on the financial well-being of residents. In general, enterprise zones (EZs) create incentives for job creation and/or capital investment in areas containing or adjacent to concentrated poverty (Neumark and Simpson 2015). Thus, in Ladd's (1994) categorization, the TEZP is an example of a place-based people strategy. In Neumark and Simpson's (2015) terminology, the TEZP can be further described as a "direct" place-based people strategy in that the program seeks to improve the well-being of residents in or around disadvantaged areas through improved local labor market conditions rather than relocating such individuals. While discussed in more detail in the next section, the goal of the TEZP is to create "an economic development tool for local communities to partner with the State of Texas to promote job creation and significant private investment that will assist economically distressed areas of the state."

Numerous empirical evaluations of EZs have appeared in the recent literature. As these are extensively reviewed in Neumark and Simpson (2015), we do not provide a detailed account of the existing literature, but rather highlight a few key points. First, Accetturo and de Blasio (2012, p. 15) state that "while area-based programs are widely implemented, much less is known about their effectiveness in reaching their stated goals." Briant et al. $(2015$, p. 88) affirm that "the evaluation of enterprise zones has generated a lot of research since the 1990s, with conflicting conclusions regarding their effectiveness." Neumark and Simpson (2015, p. 1197?) conclude that the "evidence on enterprise zones is very mixed." Second, the majority of existing studies focus on traditional labor market outcomes such as employment, wages, and poverty rates. Third, identification of causal effects of EZs necessitates attention to numerous issues:

\footnotetext{
${ }^{4}$ See https://texaswideopenforbusiness.com/services/tax-incentives.
} 
measurement of enterprise zone boundaries, choice of control locations, isolation of EZ effects from those of other policies, and spillovers (Neumark and Simpson 2015).

Our analysis of the TEZP adds to the current literature along several dimensions. First, and foremost, we move beyond a "narrow" focus on employment and wages and assess the causal effect of the program on the financial well-being of residents. Specifically, we utilize detailed information on all household debts, delinquencies, and credit scores from the Federal Reserve Bank of New York Consumer Credit Panel/Equifax, a quarterly longitudinal 5\% random sample of all individuals in the US with a social security number and a credit report. As a result, we are able to assess the impact of enterprise zones on the financial situation of residents. This responds to calls in the literature for a "more comprehensive estimation" of "additional welfare indicators" (Accetturo and de Blasio 2012, p. 24). In addition, by examining delinquencies, bankruptcies, and credit scores, we are able to focus on outcomes that speak directly to the status of disadvantaged individuals living in the target areas. Outcomes directly related to the welfare of the disadvantaged are less common in the current EZ literature (Hellerstein and Neumark 2012).

Second, the TEZP avoids many of the identification issues raised above. Zone boundaries under the program correspond to Census block groups, thereby avoiding measurement error in coverage. Program rules defining zones are straightforward and transparent, making the choice of control locations - and resulting identification assumptions also straightforward and transparent. The existence of other local benefits through the federal Empowerment Zone, Renewal Community, or Enterprise Community programs is addressed in the sample construction. Spillovers can be tested. Indeed, Freedman (2013) employs an identical identification strategy as we adopt here to assess the causal effect of the TEZP on employment growth, population characteristics, and housing market conditions. He finds positive effects on employment growth in lower-paying industries and median home values and a negative effect on the vacancy rate.

Prior to continuing, it is necessary to comment on the importance of moving beyond employment and wage outcomes when assessing the benefits of EZs. Glaeser and Gottlieb (2008), Moretti (2011), and Kline and Moretti (2014) discuss the welfare implications of placebased policies after accounting for worker mobility and housing rents. One standard result is that with perfectly mobile workers and perfectly inelastic housing supply, all benefits of place-based 
policies will be capitalized into land rents. In this case, employment and wage impacts of such policies provide a very misleading measure of the benefit to non-landowners. Moretti (2011, p. 1297) writes: "In the case of high elasticity of local labor supply and less than infinite elasticity of housing supply, this increase in housing prices will offset most of the welfare gains that might otherwise accrue to existing residents... In this setting, location-based redistributive policies intended to help areas with low nominal income have virtually no effect on the utility of workers. The only beneficiaries of this policy are landowners in the targeted areas." Briant et al. (2015, p. 93) affirm that the result could be the "capture" of the benefits of place-based policies by "untargeted populations."

Indeed, the existing empirical studies that do examine mobility and housing market conditions suggest that this straightforward theoretical result may not be unrealistic. Freedman (2013) finds an $11.3 \%$ increase in median home values in locations covered under the TEZP. Krupka and Noonan (2009) and Busso et al. (2013) document large increases - between roughly 25 and 40 percent - in house values in US federal EZs. Hanson (2009) finds an increase in median, self-reported property values of over $\$ 100,000$ in US federal EZs. Reynolds and Rohlin (2015) find an increase in house values for houses valued above $\$ 100,000$. Engberg and Greenbaum (1999) analyze state-level EZ programs and document an increase in housing values in areas with initially low vacancy rates. However, the evidence on the rental price of housing is much weaker. Busso et al. (2013) and Reynolds and Rohlin (2015), for example, find little to no impact on rents.

The empirical evidence linking place-based policies with worker mobility is also much weaker. Krupka and Noonan (2009) actually find negative effects of US federal EZs on population density and positive effects on vacancy rates. Busso et al. (2013) find no statistically significant effects on population or vacancy rates. On the other hand, Freedman (2013) documents a four percent decline in vacancy rates under the TEZP, but no statistically significant change in the population. Reynolds and Rohlin (2015) find some evidence of a polarizing impact of US federal EZs; the density of low- and high-income households increase, whereas the density of middle-income households declines.

In sum, the impact of place-based policies on the welfare of residents depends on the combined effects of such policies on the labor market and the cost of living, which in turn depend on worker mobility and housing supply. While the net effect is difficult to measure 
directly, examination of the financial well-being of residents - using detailed information found in individual credit reports - allows us to better assess the efficacy of EZs (as implemented under the TEZP). In doing so, we find little beneficial causal impact of the TEZP on the financial wellbeing of residents. At best, we find a modest positive impact on the repayment of retail loans. However, we find evidence of an increase in the delinquency rates of auto loans, as well as in Chapter 13 bankruptcy filings.

The rest of the paper is as follows. Section 2 provides some background on the TEZP. Section 3 discusses the empirical methodology and data. Section 4 presents our findings. Section 5 concludes.

\section{The Texas Enterprise Zone Program}

In the 2000 Census, Texas was divided into 254 counties, 4,388 census tracts, and 14,463 block groups. Beginning in 2003, census block groups are designated as an EZ under the Texas Enterprise Zone Program (TEZP) according to a deterministic set of rules. ${ }^{5}$ Block groups qualify as an EZ if they satisfy one of the following criteria. First, the area is designated as a federal Empowerment Zone, Renewal Community, or Enterprise Community. Introduced in 1993, all three designations are no longer in effect. Enterprise Community designations expired in 2004, while Renewal Community designations expired at the end of 2009. Empowerment Zone designations received several extensions during the Great Recession, but ultimately were allowed to expire on December $31,2014 .^{6}$ Second, the block group has a poverty rate exceeding $20 \%$ in the latest decennial census. Finally, beginning in 2005, a block group could gain the EZ designation under the TEZP if it is part of a so-called 'distressed county.' A county is labelled as distressed on an annual basis if its poverty rate exceeds $15.4 \%$, more than $25.4 \%$ of the population has less than a high school education, and the unemployment rate exceeds $4.9 \%$ in each of the prior five years.

Figure 1 shows the block groups covered under the TEZP in 2005. Areas shown in black qualify as part of the TEZP solely because the poverty rate exceeds $20 \%$. Areas shown in gray qualify due to being located in a distressed county or in a Federal Empowerment Zone, Renewal Community, or Enterprise Community.

\footnotetext{
${ }^{5}$ Refer to https://texaswideopenforbusiness.com/services/tax-incentives.

${ }^{6}$ Texas contained two Empowerment Zones (San Antonio and El Paso) and two Renewal Communities (Corpus Christi and El Paso).
} 
Once a block group is designated as an EZ under the TEZP, the locality may nominate businesses as Enterprise Projects. The projects must then be approved by the state. Businesses operating qualified projects are entitled to benefits for up to five years. State incentives take the form of state sales and use tax refunds, with the size of the refunds depending on the level of capital investment and the number of new jobs announced in the project proposal.

For a project to be approved by the state, it must generate new employment. To be counted as a new job, the job must entail at least 1,820 hours per year and the job must remain in existence throughout the benefit window or three years after benefits are initially received, whichever is later. The state approves up to a maximum of 105 projects per biennium.

Unlike the federal program, the Texas program does not require the business to locate strictly inside the boundary of an EZ. However, stricter requirements apply if the business is located outside the EZ border. If the project is located inside an EZ, 25\% of the new jobs created must be filled by individuals deemed economically disadvantaged or who meet EZ residency requirements. If the project is located outside the EZ, $35 \%$ of the new jobs created must satisfy these requirements. Between 2003 and 2014, 260 out of the 486 projects were located outside of an EZ. Projects that are not in an EZ are not far away. According to Freeman (2013), 85\% of projects between September 2003 and September 2010 were located within at least five kilometers of an EZ, over 99\% of Enterprise Projects were located within 20 kilometers of an EZ.

The maximum allowable state tax refund per job created ranges from $\$ 2500 /$ job to $\$ 7500 /$ job, with the precise amount depending of the level of capital investment. ${ }^{7}$ Table 1 shows the number of projects approved under the TEZP and the estimated maximum tax refund earned based on the tax incentive schedule. ${ }^{8}$ Between 2004 and 2014, nearly 55,000 new jobs were announced in EZ applications, with capital investment totaling roughly $\$ 60$ billion, and the estimated maximum tax refund totaling approximately $\$ 162$ million. About 30 percent of the capital investment and 48 percent of estimated maximum tax refund are attributable to business located in an EZ. Other local incentives may include "tax abatement, a refund of local sales and

\footnotetext{
${ }^{7}$ See https://texaswideopenforbusiness.com/services/tax-incentives.

${ }^{8} \mathrm{See}$ https://texaswideopenforbusiness.com/services/tax-incentives. The program charges a fee of $3 \%$ of the amount of refund.
} 
use taxes, waiver of permitting fees, tax increment financing, transfer of publicly owned buildings at below market cost, and low interest loans." 9

It should be noted that, to our knowledge, there is limited auditing by the state to ensure that the number of announced new jobs are in fact created and filled according to the guidelines.

\section{Empirics}

\section{A. Baseline Model}

With our baseline model we seek to estimate the causal effect of EZ designation under the TEZP on a variety of outcomes related to the financial well-being of residents. As noted in Hellerstein and Neumark (2012) and Neumark and Simpson (2015), causal evaluations of placebased programs confront two econometric challenges. First, often the boundaries of the program do not align with the boundaries available in the data. This results in a problem of measurement error. Second, as locations covered by placed-based programs are not chosen at random, overcoming selection bias is critical. This entails carefully choosing areas to be included in the control group.

Fortunately, the design of the TEZP makes it relatively straightforward to overcome these challenges. First, areas designated EZs under the TEZP follow the census block group boundaries. Thus, the boundaries used under the program align perfectly with the data used in the analysis. Second, the institutional rules of the TEZP allow one to utilize a regression discontinuity (RD) approach to estimate the impact of the TEZP (Lee and Lemieux 2010).

Following Freedman (2013), we estimate the impact of the TEZP on local consumer finance using the following basic estimating equation

$$
\Delta y_{i}=\beta_{0}+\beta_{1} E Z_{i}+f\left(p_{i}\right)+\boldsymbol{x}_{\boldsymbol{i}} \boldsymbol{\beta}_{2}+\varepsilon_{i},
$$

where $\Delta y_{i}$ is the change in the outcome measure, $y$, from 2002:Q4 to the terminal period (either 2006:Q4 or 2009:Q4) for census block group $i, E Z_{i}$ is a binary variable equal to one if location $i$ is an EZ, $p_{i}$ is the census block group poverty rate, $\boldsymbol{x}_{\boldsymbol{i}}$ is a vector of baseline covariates, and $\varepsilon_{i}$ is a mean zero error term allowed to be arbitrarily correlated within counties.

In our estimation sample, we exclude census block groups that are located in a distressed county or in a Federal Empowerment Zone, Renewal Community, or Enterprise Community. ${ }^{10}$

\footnotetext{
${ }^{9} \mathrm{See}$ https://texaswideopenforbusiness.com/sites/default/files/frequently_asked_questions.doc.
} 
Thus, the model in (1) fits nicely in the sharp $\mathrm{RD}$ framework, where $f(\cdot)$ is a control function with the following general form

$$
f\left(p_{i}\right)=\sum_{k=1}^{K}\left[\theta_{1 k}\left(p_{i}-0.2\right)^{k}+\theta_{2 k} E Z_{i}\left(p_{i}-0.2\right)^{k}\right],
$$

and $K$ is the order of the polynomial. Thus, the relationships between the poverty rate and the outcomes are allowed to be different on opposite sides of the cutoff (i.e., a poverty rate of $20 \%$ ). This permits heterogeneity of the function across the threshold (see also Freedman 2012, Bronzini and Iachini 2014).

Prior to continuing, two comments are warranted. First, in the sharp RD approach, the key identifying assumption that must hold for $\beta_{1}$ to have a causal interpretation is that census block groups are sufficiently similar in a narrow window around the poverty rate cutoff of $20 \%$. In our baseline specification, we only include census block groups with a poverty rate between 18 and 22 percent. Figure 2 shows the treatment and control block groups used in the estimation. However, despite using this narrow window, identification still requires localities being unable to manipulate which side of the cutoff they lie. As discussed in Freedman (2013), this is extremely unlikely in our context given the usage of the Decennial Census to measure census block group poverty rates and the fact that the 2000 Decennial Census was not used to determine TEZP inclusion until 2003. Moreover, Figure 3 reveals no bunching around the cutoff.

Second, while the RD approach overcomes the selection issue under fairly innocuous assumptions, it does so at the expense of what can be learned. If the causal effect of EZs under the TEZP is heterogeneous, then the RD estimate of $\beta_{1}$ represents a local average treatment effect (LATE). Specifically, it is the weighted average of the effects of EZ designation under the program on census block groups near the cutoff, where the weights are proportional to the $e x$ ante probability of having a poverty rate near the $20 \%$ cutoff (Freedman 2013).

\section{B. Modeling Spillovers}

A frequently voiced concern regarding place-based policies is that any gains enjoyed by targeted locations come at the expense of adjacent, non-targeted locations (Neumark and Simpson 2015). This has two salient implications. First, estimated treatment effects may overstate the benefits to targeted locations if adjacent locations are in the control group. Second,

\footnotetext{
${ }^{10}$ A similar strategy of excluding locations covered by multiple programs is pursued in Ham et al. (2011) and Freedman (2013).
} 
the net benefits of such policies may be zero if the harm done to non-targeted locations offset the gains to the targeted locations. If so, rather than promoting job creation, such policies would simply spatially redistribute economic activity. However, it is also plausible that positive spillovers may be generated through agglomeration externalities. In the case of the TEZP, positive spillovers may also arise because the program does not require that projects be physically located within an EZ.

To address these issues, we perform the following two exercises. First, we re-estimate the model in (1) excluding census block groups that border any EZ under the TEZP (i.e., regardless of whether they border a block group that qualifies for EZ status based on the 20\% poverty rate rule, the distressed county designation, or the Federal Empowerment Zone, Renewal Community, or Enterprise Community designation) from the control group. If the estimated treatment effects become muted (amplified) after eliminating adjacent census block groups from the control group, then this is consistent with negative (positive) externalities from the program on adjacent locations. ${ }^{11}$ Figure $\mathrm{A} 1$ in the appendix shows the treatment and control block groups used in this case.

Second, we directly estimate the causal impact of adjacency to an EZ on non-EZs using a sharp RD approach similar to the baseline model. ${ }^{12}$ Specifically, our estimating equation is

$$
\Delta y_{i}=\beta_{0}+\beta_{1} A D J_{i}+f\left(\operatorname{maxp}_{i}\right)+\boldsymbol{x}_{\boldsymbol{i}} \boldsymbol{\beta}_{2}+\varepsilon_{i},
$$

where $A D J_{i}$ is a binary variable equal to one if location $i$ is not an EZ but is adjacent to an EZ, $\operatorname{maxp}_{i}$ is the maximum poverty rate among all census block groups adjacent to census block group $i$, and all other notation is previously defined. The control function, $f(\cdot)$, has the following general form

$$
f\left(p_{i}\right)=\sum_{k=1}^{K}\left[\theta_{1 k}\left(\operatorname{maxp}_{i}-0.2\right)^{k}+\theta_{2 k} E Z_{i}\left(\operatorname{maxp}_{i}-0.2\right)^{k}\right]
$$

again allowing the relationships between the maximum poverty rate of adjacent block groups and the outcomes to differ on opposite sides of the cutoff.

When estimating (3), the sample is restricted to non-EZs with a poverty rate between 15 and (strictly less than) 20 percent, that do not border a distressed county or a Federal Empowerment Zone, Renewal Community, or Enterprise Community, and whose maximum poverty rate among all neighboring census block groups is between 18 and 22 percent. Thus, $\beta_{1}$

\footnotetext{
${ }^{11}$ A similar strategy is pursued in Kolko and Neumark (2010), Freedman (2012, 2013), and Gobillon et al. (2013).

${ }^{12}$ A similar strategy is pursued in Ham et al. (2011), Givord et al. (2013), and Hanson and Rohlin (2013).
} 
is identified by comparing non-EZs surrounded by locations below the $20 \%$ cutoff (and not otherwise classified as an EZ due to the distressed county designation or the federal programs) to non-EZs adjacent to at least one census block group with a poverty rate exceeding the $20 \%$ cutoff. As in the baseline model, $\beta_{1}$ should be interpreted as a LATE. Figure A2 in the appendix shows the treatment and control block groups used to estimate (3).

\section{Data}

The data are obtained from a variety of sources. Data on the TEZP span 2003-2009 and come from the Economic Development and Tourism Division (EDT) of the Texas Governor's Office. Data on federal Empowerment Zones, Renewal Communities, and Enterprise Communities are obtained from the US Department of Housing and Urban Development. ${ }^{13}$ Data on census block group baseline covariates are obtained from the 2000 Decennial Census.

Data on consumer finances are obtained from Equifax via the Federal Reserve Bank of New York Consumer Credit Panel/Equifax (CCP/Equifax). The CCP/Equifax is a quarterly longitudinal 5\% random sample of all individuals in the US with a social security number and credit report. ${ }^{14}$ Specifically, the data contain information culled from all quarterly credit reports belonging to individuals with social security numbers ending in one of five arbitrary two-digit combinations. Since the same set of five two-digit combinations are used each quarter, the data form a panel as the same individuals are included each quarter assuming they continue to have an open credit report. The CCP/Equifax began in 1999 and continues at present. We construct the dependent variables, $\Delta y$, using 2002:Q4 and either 2006:Q4 or 2009:Q4, where the earlier termination period is used in order to pre-date the onset of the Great Recession.

The CCP/Equifax contains all information found on Equifax's credit report and nothing more. As such, in terms of demographics, the only information available are the individual's year of birth and census block group corresponding to the address on file for the credit report. In terms of credit information, however, the data are extensive. To begin, there are several summary variables such as Equifax's credit risk score, indicators for Chapter 7 and Chapter 13 bankruptcy, number of credit inquiries in the past three, 12, and 24 months, and the number of new accounts opened in the past six and 12 months. In terms of detailed credit information, we

\footnotetext{
${ }^{13}$ See http://egis.hud.gov/ezrclocator/.

${ }^{14}$ Lee and van der Klaauw (2010) provide an extensive overview of the data.
} 
utilize data on auto loans, bank cards, first mortgages, and retail loans. ${ }^{15}$ For each type of credit, we know for each consumer (i) the number of open accounts, (ii) the amount of outstanding debt, (iii) the amount of debt that is current, (iv) the amount of debt that is delinquent (i.e., at least 30 days past due), (v) the number of open accounts that are severely delinquent (i.e., at least 90 days past due), and (vi) whether the consumer is in Chapter 7 or Chapter 13 bankruptcy. As noted in Livshits (2015), delinquencies are important as they are a sign of financial distress, represent the first-stage of default, and often lead to penalties such as late fees or higher interest rates.

We aggregate this information to the census block group level to form the following outcomes of interest: median Equifax credit risk score, percentage of prime (above 680), near prime (620-680), and sub-prime (below 620) risk scores, percentage in Chapter 7 and Chapter 13 bankruptcy, median number of credit inquiries and new accounts opened, percentage of auto loans, credit cards, retail loans, first mortgages, and all debts that are delinquent, percent of borrowers that are severely delinquent or in bankruptcy, and the median amount of outstanding debt of each type.

Summary statistics are provided in Tables A1-A3. Table A1 provides summary statistics for the demographic characteristics. Tables A2-A3 contain summary statistics for the credit variables. Table A2 describes the changes in credit outcomes from 2002:Q4-2006:Q4. Table A3 describes the changes in credit outcomes from 2002:Q4-2009:Q4. In each table, the summary statistics are broken down into different groups. The columns labelled "Full Sample" include all EZs (qualifying only via the $20 \%$ poverty rate cutoff) or all non-EZs. The columns labelled "BW $=0.02$ " restrict the sample to census block groups within a two percent bandwidth (BW) around the $20 \%$ cutoff. Specifically, the sample is restricted to EZs (qualifying only via the 20\% poverty rate cutoff) with a poverty rate between 20 and 22 percent and non-EZs with a poverty rate between 18 and (strictly less than) 20 percent. This sample of EZs and non-EZs with poverty rates between 18 and 22 percent constitutes our primary estimation sample, producing a sample of 1,001 census block groups over the 2002:Q4-2006:Q4 period and 1,000 census block groups over the 2002:Q4-2009:Q4 period.

\footnotetext{
${ }^{15}$ Auto loans include "loans taken out to purchase a car, including Auto Bank loans provided by banking institutions (banks, credit unions, savings and loan associations), and Auto Finance loans, provided by automobile dealers and automobile financing companies." Bank cards (or credit cards) are "revolving accounts for banks, bankcard companies, national credit card companies, credit unions and savings \& loan associations." Retail loans include loans from specific retail outlets such as clothing stores, grocery stores, department stores, home furnishing stores, gas stations, etc. See https://www.newyorkfed.org/medialibrary/interactives/householdcredit/data/pdf/data_dictionary_HHDC.pdf.
} 
The most important takeaway from the summary statistics is the fact that the treatment and control groups are very similar in terms of baseline demographic characteristics once the sample is restricted to census block groups within the two percent bandwidth around the $20 \%$ cutoff (Table A1). Obviously the poverty rate becomes more similar; the difference in means falls from 23 to two percentage points moving from the full sample to the estimation sample. The treatment and control groups also become noticeably more similar in terms of population size, size of the labor force, racial composition, educational distribution, median household income, and housing market attributes.

In terms of changes in credit outcomes, a few interesting patterns emerge after focusing on the restricted sample of census block groups within the two percent bandwidth around the $20 \%$ cutoff. First, the average increase in the median risk score is modestly higher in the treatment group than the control group over the 2002:Q4-2006:Q4 period, but not over the 2002:Q4-2009:Q4 period. Second, the average change in the median number of new inquiries over the past three or 12 months is greater (or less negative) in the treatment group than control group regardless of the sample period. The average change in the median number of new revolving accounts in the past six months is noticeably greater in the treatment group over the 2002:Q4-2006:Q4 period. Third, changes in the various measures for auto, bank card, mortgage, and retail loans are predominantly similar across the treatment and control groups. The only real discrepancies arise when examining the average change in median auto loan and mortgage loan balances. In each case, median balances increased by more, on average, in the control group.

While the summary statistics are interesting, they do not control for differences in the poverty rate - and small differences in demographic characteristics - across the treatment and control groups. So, we now turn to the sharp RD estimates.

\section{Results}

\section{A. Baseline Specification}

The baseline results, based on equation (1) using the two percent bandwidth, are presented in Table 2 and 3. Table 2 provides the results for the aggregate financial outcomes, while Table 3 presents the results for specific loan types. Each table presents results over the 2002:Q4-2006:Q4 and 2002:Q4-2009:Q4 periods. 
In Table 2, the causal effect of EZ designation is statistically significant for only one of 22 outcomes - change in the percentage of residents filing Chapter 13 bankruptcy over the 2002:Q4-2006:Q4 period - and the effect is positive. None of the remaining coefficient estimates are statistically significant at even the $\mathrm{p}<0.10$ level. Thus, as measured by overall financial well-being, there is no evidence that EZ designation under the TEZP improved the welfare of residents, and perhaps some evidence to the contrary. Moreover, the adverse impact on bankruptcy filings is noteworthy given the more than three-fold rise in the personal bankruptcy rate in the US between 1980 and 2000 (Livshits 2015).

Turning to the analysis of specific loan types, several findings emerge. ${ }^{16}$ First, over the 2002:Q4-2006:Q4 period, there exists a positive and statistically significant effect of EZ designation on the change in percentage of borrowers delinquent on auto loans $\left(\beta_{1}=0.075\right.$, s.e. $=0.030)$, as well as the change in percentage of auto loan balances in delinquency $\left(\beta_{1}=0.029\right.$, s.e. $=0.016)$. This is consistent with increased transportation needs among low income workers, but without a commensurate increase in earnings. However, the effect of EZ designation on the change in percentage of auto loan borrowers, while positive, is not statistically significant at conventional levels. Moreover, the effects are no longer statistically significant over the 2002:Q4-2009:Q4 period, although the point estimates on the three measures of delinquency continue to be positive.

Second, over the 2002:Q4-2006:Q4 period, the causal effects of EZ designation on the change in median mortgage loan and retail loan balances are positive and statistically significant (mortgage loans: $\beta_{1}=255.42$, s.e. $=140.49$; retail loans: $\beta_{1}=3.132$, s.e. $=1.569$ ). The effect on retails loans continues to be modestly statistically significant over the 2002:Q4-2009:Q4 period $\left(\beta_{1}=3.068\right.$, s.e. $\left.=1.661\right)$, but not for mortgage loans (although the point estimate continues to be positive).

Third, the causal effects of EZ designation on the three measures of delinquency for retail loans are negative across both time periods, and statistically significant for two of the three measures in the 2002:Q4-2009:Q4 period (borrowers severely delinquent: $\beta_{1}=-0.098$, s.e. $=$ 0.046 ; balance delinquent: $\beta_{1}=-0.114$, s.e. $=0.066$ ). However, for mortgage loans, we obtain the opposite findings. Specifically, the causal effects of EZ designation on the three measures of

\footnotetext{
${ }^{16}$ Note, the sample sizes are smaller for the three delinquency outcomes as the percentage of delinquent accounts or balance for a certain type of loan is computed only using individuals with that type of account. As a result, some block groups do not have any individuals in the sample in certain years with a particular type of account.
} 
delinquency are positive across both time periods, and statistically significant for one of the three measures in the 2002:Q4-2009:Q4 period (balance delinquent: $\beta_{1}=0.097$, s.e. $=0.057$ ).

Finally, there is no statistically meaningful evidence of a causal effect of EZ designation on changes in bank card activity, or on the change in percentage of individuals partaking in the different types of loans (although the point estimates are generally positive).

To assess the magnitudes of the effects that are statistically significant at conventional levels, it is useful to compare the point estimates to the standard deviations (SD) of the outcomes for non-EZs. Doing so indicates that the impacts on changes in the median balances of mortgage and retail loans are small. For example, an increase in the median mortgage loan balance of \$255 over the 2002:Q4-2006:Q4 period represents slightly more than a 0.1SD gain. An increase in the median retail loan balance of \$3 over the 2002:Q4-2006:Q4 (2002:Q4-2009:Q4) period represents less than a $0.1 \mathrm{SD}(0.2 \mathrm{SD})$ gain. However, the positive effect on percentage of auto loan borrowers delinquent over the 2002:Q4-2006:Q4 period is meaningful (over 0.5SD), as is the negative effect of retail loan delinquencies over the 2002:Q4-2009:Q4 period (approximately 0.4-0.5SD).

In sum, the overall results point to a minimal impact of EZ designation under the TEZP on the overall financial well-being of individuals. While there is some evidence of a beneficial effect as it relates to retail loans, there is also evidence of adverse effects on auto loan and mortgage delinquency and Chapter 13 bankruptcy filings. ${ }^{17}$ The modest impact is consistent with the analysis of the TEZP in Freedman (2013). He finds positive effects on employment growth, but concentrated among low-paying jobs (see also Bondonio and Greenbaum 2007, Mayer et al. 2015). Moreover, he documents a significant rise in home values and fall in vacancy rates. Thus, Freedman's (2013, p. 342) conjecture that these findings "tend to erode any improvement in overall welfare owing to the program" appears on the mark. Moreover, our results are in line with the standard theoretical result, discussed in Kline and Moretti (2014), that all gains from place-based policies are capitalized into land values if labor is perfectly mobile and housing supply is perfectly inelastic.

Before turning to additional specifications to test for spillovers, we conduct two sensitivity analyses. First, we explore the impact of using alternative bandwidths $-0.01,0.03$,

\footnotetext{
${ }^{17}$ Note, retail loans account for a small fraction of consumer debt. In Texas in 2014:Q4, per capita total debt was nearly $\$ 40,000$. Of this, consumer finance loans (including sales financing and personal loans) and retail loans make up about 5\% (Federal Reserve Bank of New York 2015).
} 
0.05, and 0.10 - around the cutoff. The results are provided in Tables A4-A9 in the appendix. Tables A4 and A5 contain the results for the aggregate financial outcomes over the 2002:Q42006:Q4 and 2002:Q4-2009:Q4 periods, respectively. Tables A6-A9 contain the results for auto loans, bank cards, mortgage loans, and retail loans, respectively.

In terms of aggregate financial outcomes, the most salient finding is that EZ designation has a positive and statistically significant effect on the change in percentage of individuals in Chapter 13 bankruptcy across the majority of bandwidths in both time periods. Chapter 13 "provides for adjustment of debts of an individual with regular income" and "allows a debtor to keep property and pay debts over time, usually three to five years." 18 The increase in prevalence of Chapter 13 bankruptcies in EZs - which account for about 30\% of all bankruptcy filings in the US - may be a positive if it coincides with a decline in Chapter 7 bankruptcies since Chapter 13 allows borrowers to retain their assets (Livshits 2015). However, we do not find any evidence of a corresponding decline in Chapter 7 bankruptcies; the point estimates are statistically insignificant and often positive. Thus, the rise in Chapter 13 bankruptcies in EZs does not appear to a welfare-improving outcome.

Aside from the Chapter 13 bankruptcy results, the only other outcomes that produce some statistically significant results relate to credit scores and the median number of credit inquiries. With respect to credit scores, we find modest evidence of a negative (positive) and statistically significant impact on the change in percentage of individuals with a prime (near prime) risk score. This, too, is not a welfare-improving outcome. In terms of the change in median number of credit inquiries, there is modest evidence that EZ designation reduces the number of credit inquiries over the prior three or 12 months when using the 2002:Q4-2009:Q4 period.

Turning to the loan-specific results, a few findings are noteworthy. First, the positive and statistically significant effect of EZ designation on the change in the percentage of borrowers delinquent on auto loans and the percentage of auto loan balances in delinquency over the 2002:Q4-2006:Q4 period remains in the majority of cases. There is also some evidence of a positive statistically significant effect on the change in the percentage of borrowers severely delinquent on auto loans. As in Table 3, there is never any statistically significant impact on auto loans over the 2002:Q4-2009:Q4 period.

\footnotetext{
${ }^{18} \mathrm{See} \mathrm{http://www.uscourts.gov/services-forms/bankruptcy/bankruptcy-basics/chapter-13-bankruptcy-basics.}$
} 
Second, we continue to find no meaningful evidence of an effect of EZ designation on bank card activity; only two of the 40 coefficients are statistically significant at the $p<0.10$ level. Third, the positive and statistically significant impact on the change in median mortgage loan balance over the 2002:Q4-2006:Q4 period is not robust to the choice of bandwidth, nor is the effect on the change in the percent of balances in delinquency over the 2002:Q4-2009:Q4 period. However, there is modest evidence of a positive impact on the change in the percentage of severely delinquent borrowers over the 2002:Q4-2006:Q4 period, as well as the change in the percentage of mortgage holders over the 2002:Q4-2009:Q4 period, at alternative bandwidths.

Finally, the positive and statistically significant impact on the change in median retail loan balance over either time period is not robust to the choice of bandwidth. However, the reduction in retail loan delinquency measures over the 2002:Q4-2009:Q4 period as a result of EZ designation persists across the different bandwidths, with the estimates often statistically significant at conventional levels.

The next sensitivity analysis we perform entails assessing the effects of crossing placebo cutoffs. Specifically, reverting back to the two percent bandwidth, we use cutoffs of $17.5 \%$ and $22.5 \%$. For the former, we retain census block groups with a poverty rate between 15.5 and 19.5 percent, and designate block groups with a poverty rate above $17.5 \%$ as the treatment group. For the latter, we retain census block groups with a poverty rate between 20.5 and 24.5 percent, and designate block groups with a poverty rate above $22.5 \%$ as the treatment group. The results using the $17.5 \%$ cutoff are presented in Tables A10 and A11. The results using the $22.5 \%$ cutoff are presented in Tables A12 and A13.

Tables A10 and A12 contain the results for the aggregate financial outcomes. Of the 44 coefficient estimates, only three are statistically significant at the $\mathrm{p}<0.10$ level, consistent with what one would expect by chance. Tables A11 and A13 contain the results for the loan-specific outcomes. Of the 80 coefficient estimates, 11 are statistically significant at the $\mathrm{p}<0.10$ level, slightly higher than what one would expect by chance. In total, 14 of 124 coefficients estimates are statistically significant at the $\mathrm{p}<0.10$ level, or $11.3 \%$, essentially what one would expect by chance.

In conclusion, the results of the two sensitivity analyses do little to alter the findings from our baseline model. EZ designation under the TEZP has a beneficial impact on retail loan delinquency rates, but has little beneficial impact on other measures of financial well-being. In 
fact, there is some evidence of an adverse impact on auto loan and mortgage activity, as well as Chapter 13 bankruptcy filings.

\section{B. Spillovers}

As discussed above, placed-based policies may generate spillovers of nearby locations. Such spillovers may be negative if economic activity is displaced from non-EZs to EZs, or may be positive if the benefits of an EZ cross the EZ border. Moreover, in either case, the presence of spillovers may impact the estimates from the baseline model to the extent that non-EZs that are close to EZs are in the control group. In the case of the TEZP, spillovers are especially likely since the TEZP does not require projects physically locate in an EZ. The program instead places residency requirements on new hires. We now turn to the results of our investigation into the presence of spillovers.

\section{B.1. Alternative Control Group}

To begin, we alter the definition of the control group. We continue to use a two percent bandwidth, however we now exclude census block groups that border any EZ (i.e., regardless of how it qualifies as an EZ). Thus, the sample size is reduced relative to the baseline model. The results are presented in Tables 4 and 5.

In terms of the aggregate financial outcomes (Table 4), we find stronger evidence of a positive and statistically significant impact on the change in Chapter 13 bankruptcy filings (2002:Q4-2006:Q4: $\beta_{1}=0.013$, s.e. $=0.004 ; 2002: Q 4-2009: Q 4: \beta_{1}=0.012$, s.e. $=0.005$ ). None of the other effects are statistical significant at conventional levels.

Turning to the loan-specific outcomes, two findings stand out. First, we find even stronger effects on retail loan activity. Specifically, reductions in delinquency rates are even larger in magnitude and are statistically significant at conventional levels more often. We also now find some evidence of a reduction in delinquency rates of bank cards over the 2002:Q42009:Q4 period as well. Second, the positive effect and statistically significant effect of EZ designation on auto loan delinquency rates over the 2002:Q4-2006:Q4 period persists.

Together, then, the results point to spillover effects on bordering non-EZs in the same direction as the direct effects on EZs. Given the institutional rules of the TEZP, this is not surprising. However, it is in contrast with many other evaluations of place-based programs that 
find evidence of negative spillovers in terms of economic activity (e.g., Givord et al. 2013, Hanson and Rohlin 2013, Mayer et al. 2015).

\section{B.2. Alternative Treatment Definition}

Our second test for spillovers alters the definition of the treatment (and hence the control group as well). As shown in (3), the sample is restricted to census block groups with a poverty rate between 15 and (strictly less than) 20 percent. For each block group in the sample, we compute the maximum poverty rate among its contiguous neighboring block groups. The treatment group is defined as those census block groups whose maximum poverty rate among its contiguous neighboring block groups is between 20 and 22 percent. The control group is defined as those census block groups whose maximum poverty rate among its contiguous neighboring block groups is between 18 and 20 percent. Thus, this set up still aligns with the sharp RD framework. However, the sample size is small.

Results are shown in Tables 6 and 7. Among the 62 coefficient estimates, only two are statistically significant at conventional levels. As such, given the lack of precision due to the small sample size, we resist giving these results much weight.

\section{Conclusion}

Despite the long history of place-based policies playing a prominent role in regional economic development initiatives, the theoretical and empirical evidence of their efficacy is limited. The overall impact of such policies on welfare depends on their ability to generate investment and employment growth, as well as their impact on individual mobility and the costof-living. Existing studies have examined different pieces of these outcomes, making conclusions regarding overall effects on welfare difficult to draw.

Here, we explore one such program, the Texas Enterprise Zone Program. Taking advantage of the unique institutional rules of the Texas program, along with unique data provided by the Federal Reserve Bank of New York Consumer Credit Panel/Equifax, we are able to assess the direct impact of the program on the financial well-being of residents. In doing so, we find little beneficial causal impact of the program. At best, we find a modest positive impact on the repayment of retail loans. However, we also find evidence of an increase in the delinquency rates on auto loans, as well as in Chapter 13 bankruptcy filings. 
While these findings are illuminating, they also come with some caveats. First, while the regression discontinuity estimates provided here have a high degree of internal validity, their external validity is uncertain. In particular, the results may not generalize to other cutoffs aside from the $20 \%$ cutoff currently in use under the program. Moreover, the results may be specific to the peculiarities of the Texas program, such as the fact that census block groups meeting the poverty rate threshold are automatically designated as enterprise zones without having to apply, projects under the program need not physically local in an enterprise zone, and auditing of projects undertaken as a result of the program is questionable (Bondonio and Engberg 2000, Freedman 2013). In particular, Bondonio and Greenbaum (2007) find that US state enterprise zone programs are more effective if they utilize a competitive application process resulting in a small number of zones; not an attribute of the Texas program.

Second, much of the recent literature explores various sources of heterogeneity in the effects of enterprise zones. Kolko and Neumark (2010), for example, uncover several sources of heterogeneity even when focusing on a program in a single state (California). Here, we focus solely on the average effect of enterprise zone designation under the Texas program.

Nonetheless, the lack of strong evidence that the Texas program has improved the financial wellbeing of enterprise zone residents on average is significant in light of the costs involved, consistent with Glaeser and Gottlieb's (2008, p. 155) claim that enterprise zones are "expensive relative to their achievements."

\section{References}

Accetturo, A. and G. de Blasio (2012), "Policies for Local Development: An Evaluation of Italy's 'Patti Territoriali'," Regional Science and Urban Economics, 42: 15-26.

Bondonio, D. and J. Engberg (2000), "Enterprise Zones and Local Employment: Evidence from the States' Programs," Regional Science and Urban Economics, 30: 519-549.

Bondonio, D. and R.T. Greenbaum (2007), "Do Local Tax Incentives Affect Economic Growth? What Mean Impacts Miss in the Analysis of Enterprise Zones Policies," Regional Science and Urban Economics, 37(1): 121-136.

Briant, A., M. Lafourcade, and B. Schmutz (2015), "Can Tax Breaks Beat Geography? Lessons from the French Enterprise Zone Experience," American Economic Journal: Economic Policy, 7(2): 88-124.

Bronzini, R. and E. Iachini (2014), “Are Incentives for R\&D Effective? Evidence from a Regression Discontinuity Approach,” American Economic Journal: Economic Policy, 6(4): 100-134.

Busso, M., J. Gregory, and P. Kline (2013), “Assessing the Incidence and Efficiency of a Prominent Place Based Policy," American Economic Review, 103(2): 897-947. 
Engberg, J. and R. Greenbaum (1999), "State Enterprise Zones and Local Housing Markets," Journal of Housing Research, 10(2): 163-187.

Federal Reserve Bank of New York (2015), Quarterly Report on Household Debt and Credit, February.

Freedman, M. (2012), “Teaching New Markets Old Tricks: The Effects of Subsidized Investment on Low-Income Neighborhoods," Journal of Public Economics, 96(11-12): 10001014.

Freedman, M. (2013), “Targeted Business Incentives and Local Labor Markets," Journal of Human Resources, 48(2): 311-344.

Givord, P., R. Rathelot, and P. Sillard (2013), "Place-Based Tax Exemptions and Displacement Effects: An Evaluation of the Zones Franches Urbaines Program," Regional Science and Urban Economics, 43(1): 151-163

Glaeser, E. and J. Gottlieb (2008), “The Economics of Place-Making Policies,” Brookings Papers on Economic Activity, 39(1): 155-253.

Gobillon, L., T. Magnac, and H. Selod (2012), "Do Unemployed Workers Benefit from Enterprise Zones? The French Experience,” Journal of Public Economics, 96(9-10): 881892.

Ham, J., C. Swenson, A. İmrohoroğlu, and H. Song (2011), “Government Programs Can Improve Local Labor Markets: Evidence from State Enterprise Zones, Federal Empowerment Zones, and Federal Enterprise Community," Journal of Public Economics, 95(7-8): 779-797.

Hanson, A. (2009), "Local Employment, Poverty, and Property Value Effects of GeographicallyTargeted Tax Incentives: An Instrumental Variables Approach,” Regional Science and Urban Economics, 39(6): 721-731.

Hanson, A. and S. Rohlin (2013), "Do Spatially Targeted Redevelopment Programs Spillover?" Regional Science and Urban Economics, 43: 86-100.

Hellerstein, J.K. and D. Neumark (2012), "Employment Problems in Black Urban Labor Markets: Problems and Solutions," in P.N. Jefferson (ed.) The Oxford Handbook of the Economics of Poverty, Oxford: Oxford University Press, 164-202.

Kline, P. and E. Moretti (2013), "Place Based Policies with Unemployment," American Economic Review, 103(3): 238-243.

Kline, P. and E. Moretti (2014), "People, Places and Public Policy: Some Simple Welfare Economics of Local Economic Development Programs," Annual Review of Economics, 6: 629-662.

Kolko, J. and D. Neumark (2010), “Do Some Enterprise Zones Create Jobs?” Journal of Policy Analysis and Management, 29(1): 5-38.

Krupka, D.J. and D.S. Noonan (2009), "Empowerment Zones, Neighborhood Change and Owner-Occupied Housing," Regional Science and Urban Economics, 39: 386-396.

Ladd, H.F. (1994). "Spatially Targeted Economic Development Strategies: Do They Work?" Cityscape: A Journal of Policy Development and Research, 1: 193-218.

Lee, D. and T. Lemieux (2010), "Regression Discontinuity Designs in Economics," Journal of Economic Literature, 48(2): 281-355.

Lee, D. and W. van der Klaauw (2010), "An Introduction to the FRBNY Consumer Credit Panel," FRBNY Staff Report no. 479.

Mayer, T., F. Mayneris, and L. Py (2015), “The Impact of Urban Enterprise Zones on Establishment Location Decisions and Labor Market Outcomes: Evidence from France," Journal of Economic Geography, forthcoming. 
Livshits, I. (2015), "Recent Developments in Consumer Credit and Default Literature," Journal of Economic Survey, 29(4): 594-613.

Moretti, E. (2011), "Local Labor Markets," in O. Ashenfelter and D. Card (eds.) Handbook of Labor Economics 4B, Amsterdam: North- Holland, 1237-1313.

Neumark, D. and H. Simpson (2015), "Place-Based Policies," in G. Duranton, V. Henderson, and W. Strange (eds.) Handbook of Regional and Urban Economics, Vol. 5, Amsterdam: Elsevier, 1197-1287.

Reynolds, C.L. and S.M. Rohlin (2015), "The Effects of Location-Based Tax Policies on the Distribution of Household Income: Evidence from the Federal Empowerment Zone Program," Journal of Urban Economics, 88, 1-15. 


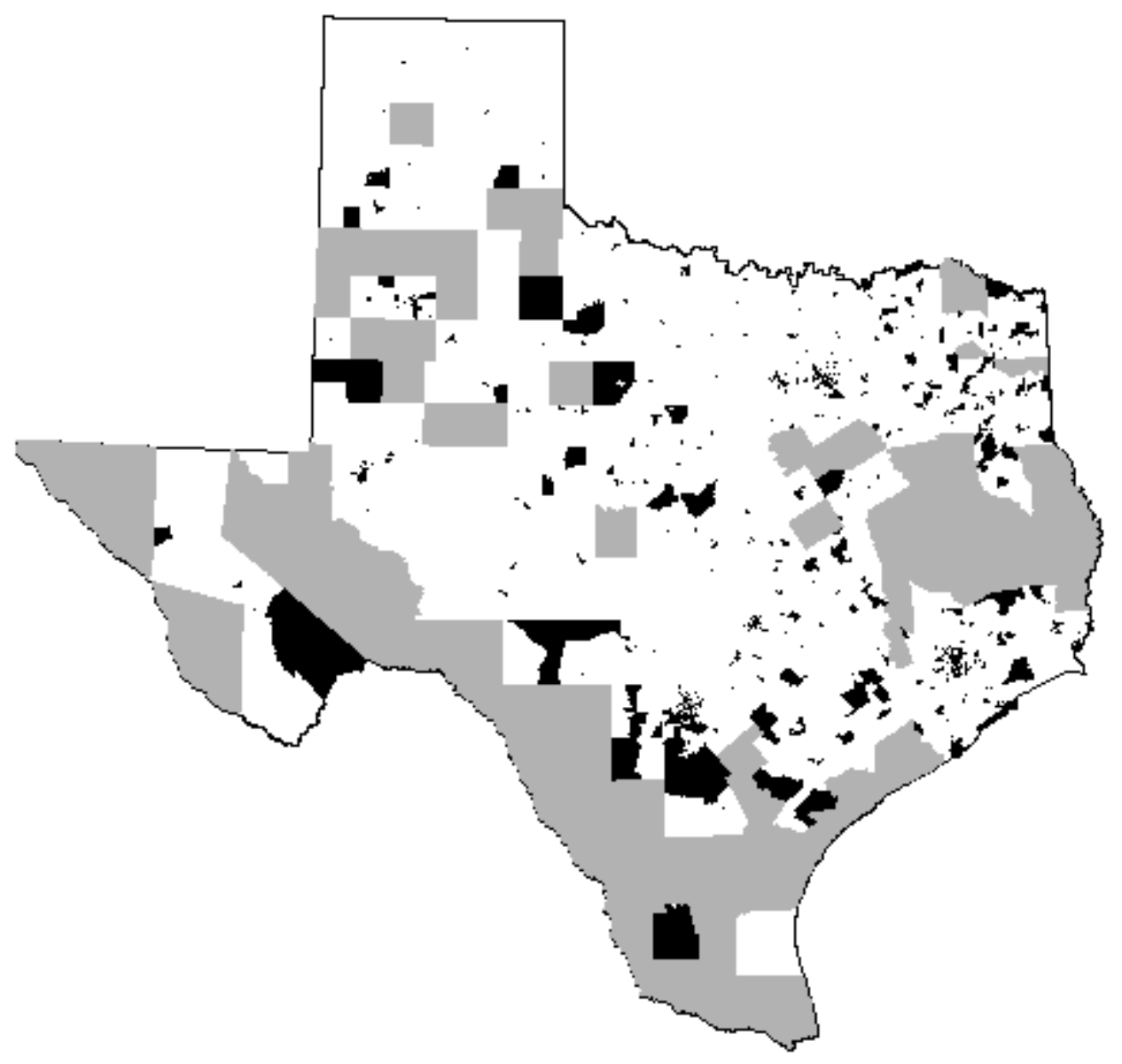

EZ Based on Other Criteria

EZ Based Only on Poverty Rate

Figure 1. Map of Texas Enterprise Zones, 2005.

Notes: Census block groups shaded in black qualify solely based on having a poverty rate above 0.20 . Census block groups shaded in gray qualify due to being located in a distressed county or in a Federal Empowerment Zone, Renewal Community, or Enterprise Community. 


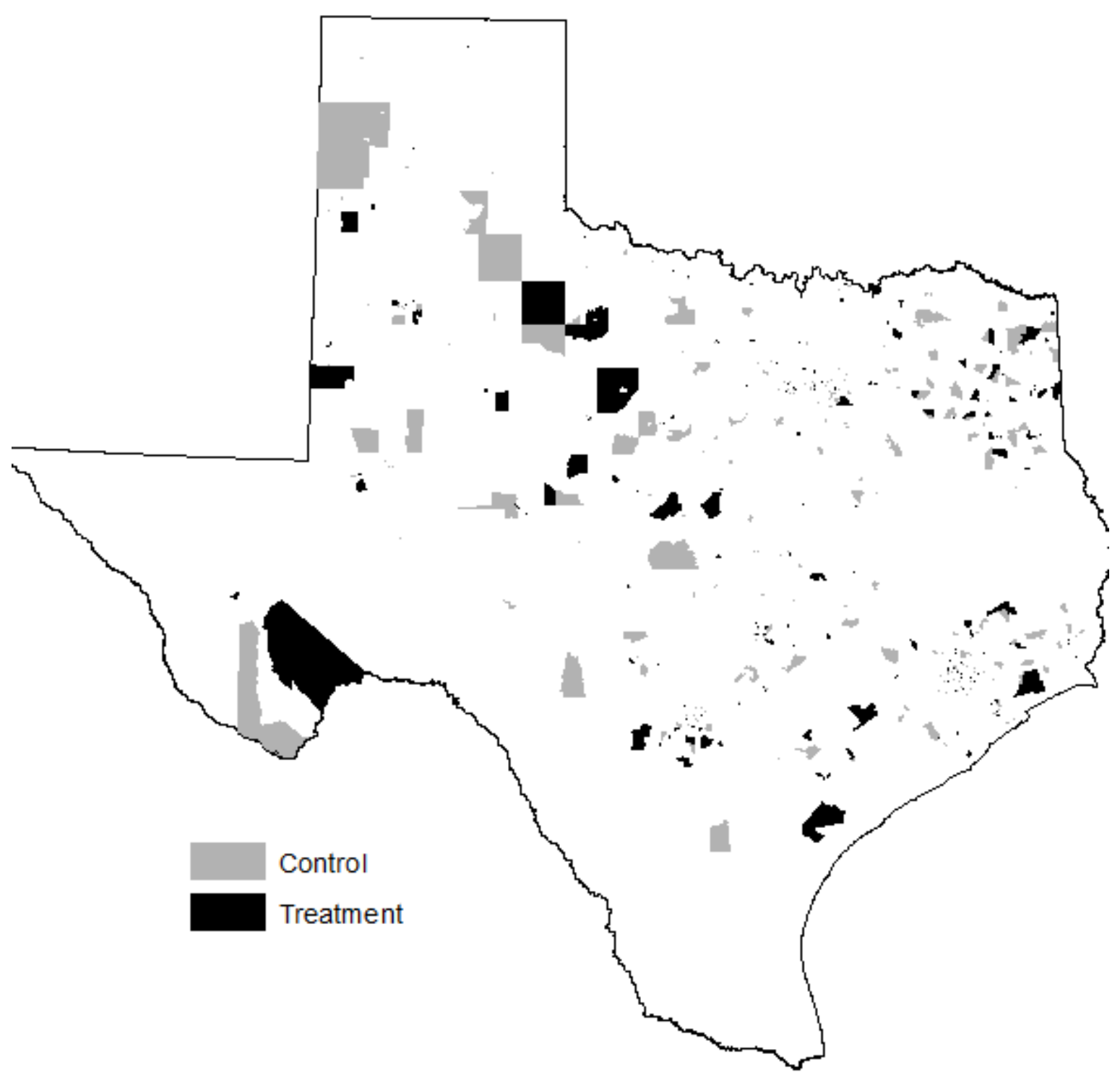

Figure 2. Map of Treatment and Control Groups.

Notes: Treatment group consists of Census block groups with a poverty rate between 0.20 and 0.22 in 2000 . Control group consists of Census block groups with a poverty rate between 0.18 and 0.20 in 2000. Census block groups located in a distressed county at any point from 2005-2009 or in a Federal Empowerment Zone, Renewal Community, or Enterprise Community are excluded. 


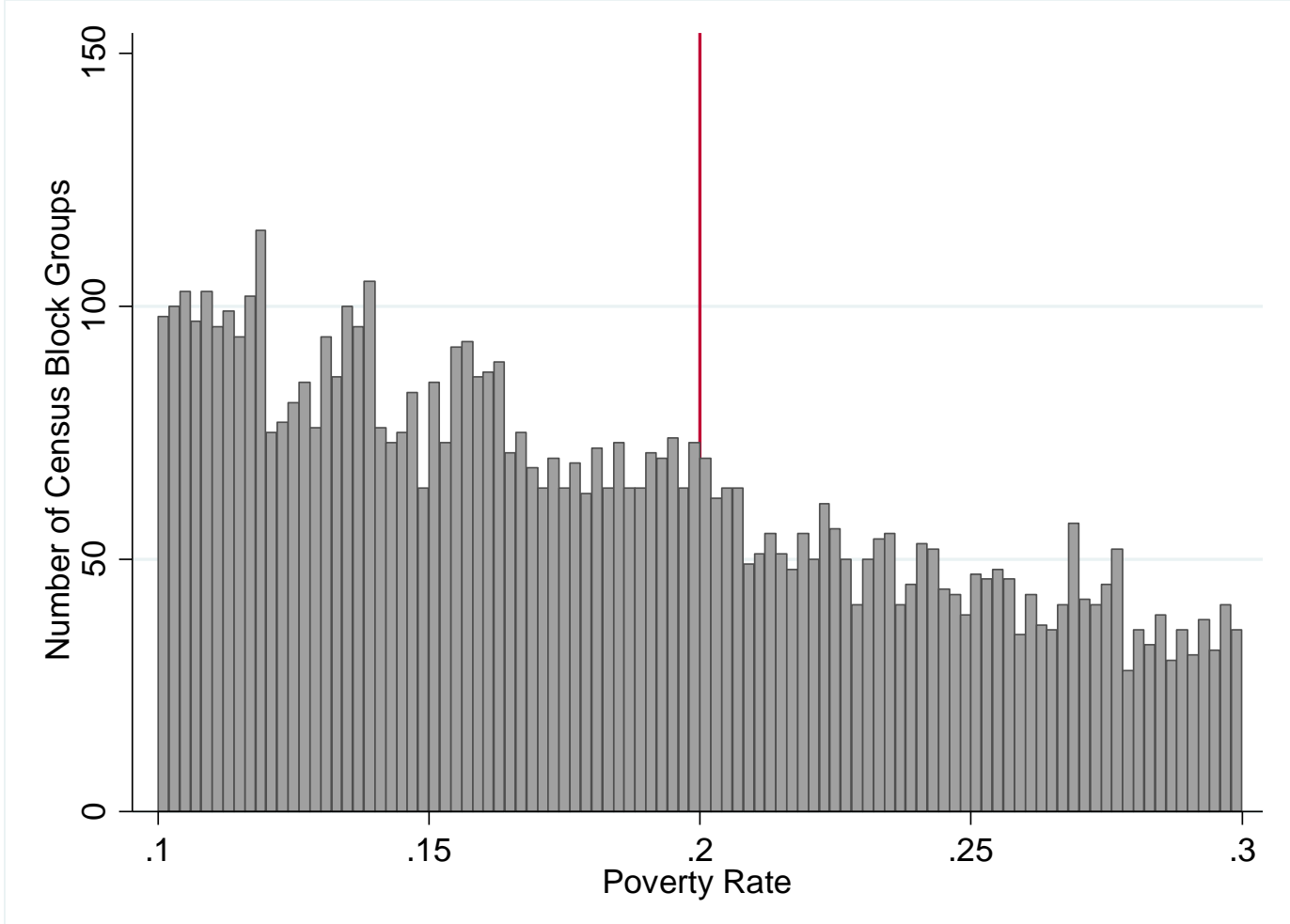

Figure 3. Density of the Forcing Variable.

Note: Count of census block groups within 0.002 bins of the poverty rate. 
Table 1. Projects Under Texas Enterprise Zone Program

\begin{tabular}{|c|c|c|c|c|c|c|c|c|}
\hline \multirow[b]{2}{*}{ Year } & \multirow{2}{*}{$\begin{array}{l}\text { Number of } \\
\text { Projects }\end{array}$} & \multicolumn{2}{|c|}{$\underline{\text { Number of New Projects }}$} & \multirow{2}{*}{$\begin{array}{c}\text { Number of } \\
\text { Announced New } \\
\text { Jobs } \\
\end{array}$} & \multicolumn{2}{|c|}{ Capital Investment } & \multicolumn{2}{|c|}{ Estimated State Max Tax Refund } \\
\hline & & Total & In an EZ & & Total (\$Mil) & In an EZ (\$Mil) & Total (\$Mil) & In an EZ (\$Mil) \\
\hline 2003 & 19 & 19 & 14 & 3,244 & 1,135 & 1,002 & 7.8 & 6.6 \\
\hline 2004 & 64 & 45 & 24 & 6,491 & 4,778 & 2,245 & 18.9 & 9.4 \\
\hline 2005 & 96 & 32 & 14 & 7,644 & 2,949 & 542 & 15.9 & 8.6 \\
\hline 2006 & 116 & 20 & 12 & 3,086 & 1,104 & 312 & 6.4 & 5.4 \\
\hline 2007 & 136 & 20 & 10 & 3,056 & 1,355 & 648 & 7.4 & 2.2 \\
\hline 2008 & 163 & 46 & 16 & 7,835 & 3,407 & 474 & 15.8 & 5.0 \\
\hline 2009 & 174 & 56 & 22 & 3,975 & 11,634 & 1,321 & 8.8 & 4.2 \\
\hline 2010 & 224 & 82 & 38 & 8,926 & 8,678 & 2,306 & 22.5 & 10.7 \\
\hline 2011 & 228 & 24 & 6 & 1,528 & 5,252 & 1,547 & 7.5 & 3.8 \\
\hline 2012 & 253 & 45 & 20 & 2,028 & 4,603 & 918 & 5.2 & 2.0 \\
\hline 2013 & 255 & 48 & 21 & 2,072 & 3,701 & 977 & 22.4 & 6.2 \\
\hline 2014 & 248 & 49 & 29 & 5,032 & 11,857 & 6,085 & 23.5 & 13.6 \\
\hline
\end{tabular}

Note: Authors' calcuation based on TEZP public record and tax incentive schedule at: https://texaswideopenforbusiness.com/services/tax-incentives. 
Table 2. Effect of Texas Enterprise Zone Program on the Change in Aggregate Financial Outcomes

\begin{tabular}{|c|c|c|c|c|c|c|c|c|c|c|c|}
\hline & $\begin{array}{c}\text { Median } \\
\text { Risk Score }\end{array}$ & $\begin{array}{c}\text { Prime Risk } \\
\text { Score } \\
\text { (Percent) }\end{array}$ & $\begin{array}{c}\text { Near Prime } \\
\text { Risk Score } \\
\text { (Percent) }\end{array}$ & $\begin{array}{c}\text { Sub-Prime } \\
\text { Risk Score } \\
\text { (Percent) }\end{array}$ & $\begin{array}{c}\text { Chapter } 7 \\
\text { Bankruptcy } \\
\text { (Percent) }\end{array}$ & $\begin{array}{c}\text { Chapter } 13 \\
\text { Bankruptcy } \\
\text { (Percent) }\end{array}$ & $\begin{array}{c}\text { Median } \\
\text { Number of } \\
\text { Credit } \\
\text { Inquiries } \\
\text { (Past } 3 \\
\text { Months) }\end{array}$ & $\begin{array}{l}\text { Median } \\
\text { Number of } \\
\text { Credit } \\
\text { Inquiries } \\
\text { (Past 12 } \\
\text { Months) }\end{array}$ & $\begin{array}{c}\text { Median } \\
\text { Number of } \\
\text { New } \\
\text { Accounts } \\
\text { (Past 6 } \\
\text { Months) }\end{array}$ & $\begin{array}{c}\text { Median } \\
\text { Number of } \\
\text { New } \\
\text { Revolving } \\
\text { Accounts } \\
\text { (Past } 6 \\
\text { Months) }\end{array}$ & $\begin{array}{c}\text { Median } \\
\text { Number of } \\
\text { New } \\
\text { Accounts } \\
\text { (Past 12 } \\
\text { Months) }\end{array}$ \\
\hline \multicolumn{12}{|c|}{ I. $\Delta(2006: Q 4-2002: Q 4)$} \\
\hline TX EZ (1 = Yes) & $\begin{array}{r}4.681 \\
(7.992)\end{array}$ & $\begin{array}{r}-0.007 \\
(0.018)\end{array}$ & $\begin{array}{r}0.001 \\
(0.013)\end{array}$ & $\begin{array}{r}0.006 \\
(0.018)\end{array}$ & $\begin{array}{r}-0.007 \\
(0.007)\end{array}$ & $\begin{array}{l}0.010 * * * \\
(0.003)\end{array}$ & $\begin{array}{r}0.765 \\
(0.744)\end{array}$ & $\begin{array}{r}1.233 \\
(0.889)\end{array}$ & $\begin{array}{r}-0.026 \\
(0.042)\end{array}$ & $\begin{array}{r}-0.551 \\
(1.605)\end{array}$ & $\begin{array}{r}0.061 \\
(0.251)\end{array}$ \\
\hline $\mathrm{N}$ & 1001 & 1001 & 1001 & 1001 & 1001 & 1001 & 1001 & 1001 & 1001 & 1001 & 1001 \\
\hline \multicolumn{12}{|c|}{ II. $\Delta(2009: Q 4-2002: Q 4)$} \\
\hline TX EZ (1 = Yes) & $\begin{array}{r}3.745 \\
(10.47)\end{array}$ & $\begin{array}{r}-0.069 \\
(0.051)\end{array}$ & $\begin{array}{r}0.032 \\
(0.024)\end{array}$ & $\begin{array}{r}0.037 \\
(0.042)\end{array}$ & $\begin{array}{r}0.001 \\
(0.008)\end{array}$ & $\begin{array}{r}0.006 \\
(0.005)\end{array}$ & $\begin{array}{r}0.905 \\
(1.548)\end{array}$ & $\begin{array}{r}1.351 \\
(1.586)\end{array}$ & $\begin{array}{r}0.000 \\
(0.021)\end{array}$ & $\begin{array}{r}-0.119 \\
(1.315)\end{array}$ & $\begin{array}{r}0.111 \\
(0.158)\end{array}$ \\
\hline $\mathrm{N}$ & 1000 & 1000 & 1000 & 1000 & 1000 & 1000 & 1000 & 1000 & 1000 & 1000 & 1000 \\
\hline
\end{tabular}

Notes: ${ }^{*} \mathrm{p}<0.10,{ }^{* *} \mathrm{p}<0.05,{ }^{* * *} \mathrm{p}<0.01$. Sample restricted to Census block groups with a poverty rate between 0.18 and 0.22 in 2000 . Number of EZs is 445 in Panels I and II. Number of non-EZs is 556 and 555 in Panels I and II, respectively. Estimation is by OLS, weighted by number of individuals in the block group. Covariates include all variables listed in Table A1 in the appendix. Standard errors are clustered at the county level. Data sources: Federal Reserve Bank of New York Consumer Credit Panel/Equifax and 2000 Decennial Census. 
Table 3. Effect of Texas Enterprise Zone Program on the Change in Aggregate Financial Outcomes by Type

\begin{tabular}{|c|c|c|c|c|c|c|c|c|c|c|}
\hline & \multicolumn{5}{|c|}{$\Delta(2006: Q 4-2002: Q 4)$} & \multicolumn{5}{|c|}{$\Delta(2009: Q 4-2002: Q 4)$} \\
\hline & $\begin{array}{c}\text { Borrowers } \\
\text { (Percent) }\end{array}$ & $\begin{array}{c}\text { Borrowers } \\
\text { Delinquent } \\
\text { (Percent) }\end{array}$ & $\begin{array}{c}\text { Borrowers } \\
\text { Severely } \\
\text { Delinquent } \\
\text { (Percent) }\end{array}$ & $\begin{array}{c}\text { Balance } \\
\text { Delinquent } \\
\text { (Percent) }\end{array}$ & $\begin{array}{l}\text { Median } \\
\text { Balance } \\
\text { (Dollars) }\end{array}$ & $\begin{array}{c}\text { Borrowers } \\
\text { (Percent) }\end{array}$ & $\begin{array}{c}\text { Borrowers } \\
\text { Delinquent } \\
\text { (Percent) }\end{array}$ & $\begin{array}{c}\text { Borrowers } \\
\text { Severely } \\
\text { Delinquent } \\
\text { (Percent) }\end{array}$ & $\begin{array}{c}\text { Balance } \\
\text { Delinquent } \\
\text { (Percent) }\end{array}$ & $\begin{array}{l}\text { Median } \\
\text { Balance } \\
\text { (Dollars) }\end{array}$ \\
\hline \multicolumn{11}{|l|}{ I. Auto Loans } \\
\hline TX EZ (1 = Yes) & $\begin{array}{c}0.002 \\
(0.02)\end{array}$ & $\begin{array}{l}0.075^{* *} \\
(0.030)\end{array}$ & $\begin{array}{r}0.019 \\
(0.027)\end{array}$ & $\begin{array}{c}0.029 \text { * } \\
(0.016)\end{array}$ & $\begin{array}{r}14.20 \\
(57.38)\end{array}$ & $\begin{array}{r}-0.039 \\
(0.062)\end{array}$ & $\begin{array}{r}0.022 \\
(0.042)\end{array}$ & $\begin{array}{r}0.040 \\
(0.028)\end{array}$ & $\begin{array}{r}0.006 \\
(0.026)\end{array}$ & $\begin{array}{r}-4097.6 \\
(3615)\end{array}$ \\
\hline $\mathrm{N}$ & 1001 & 985 & 985 & 985 & 1001 & 1000 & 987 & 987 & 987 & 1000 \\
\hline \multicolumn{11}{|l|}{ II. Bank Cards } \\
\hline TX EZ (1 = Yes) & $\begin{array}{r}0.032 \\
(0.022)\end{array}$ & $\begin{array}{r}0.005 \\
(0.025)\end{array}$ & $\begin{array}{r}-0.002 \\
(0.027)\end{array}$ & $\begin{array}{r}-0.014 \\
(0.046)\end{array}$ & $\begin{array}{r}81.61 \\
(82.11)\end{array}$ & $\begin{array}{r}0.054 \\
(0.043)\end{array}$ & $\begin{array}{r}-0.024 \\
(0.035)\end{array}$ & $\begin{array}{r}-0.023 \\
(0.041)\end{array}$ & $\begin{array}{r}0.004 \\
(0.041)\end{array}$ & $\begin{array}{r}62.00 \\
(75.21)\end{array}$ \\
\hline $\mathrm{N}$ & 1001 & 998 & 998 & 998 & 1001 & 1000 & 994 & 994 & 994 & 1000 \\
\hline \multicolumn{11}{|c|}{ III. Mortgage Loans } \\
\hline TX EZ (1 = Yes) & $\begin{array}{r}-0.001 \\
(0.015)\end{array}$ & $\begin{array}{r}0.013 \\
(0.039)\end{array}$ & $\begin{array}{r}0.016 \\
(0.024)\end{array}$ & $\begin{array}{r}0.023 \\
(0.050)\end{array}$ & $\begin{array}{l}255.42 * \\
(140.5)\end{array}$ & $\begin{array}{r}0.008 \\
(0.021)\end{array}$ & $\begin{array}{r}0.084 \\
(0.051)\end{array}$ & $\begin{array}{r}0.013 \\
(0.032)\end{array}$ & $\begin{array}{c}0.097 \text { * } \\
(0.057)\end{array}$ & $\begin{array}{r}107.04 \\
(152.0)\end{array}$ \\
\hline $\mathrm{N}$ & 1001 & 860 & 860 & 860 & 1001 & 1000 & 862 & 862 & 862 & 1000 \\
\hline \multicolumn{11}{|l|}{ IV. Retail Loans } \\
\hline TX EZ (1 = Yes) & $\begin{array}{r}0.009 \\
(0.017)\end{array}$ & $\begin{array}{r}-0.030 \\
(0.048)\end{array}$ & $\begin{array}{r}-0.046 \\
(0.042)\end{array}$ & $\begin{array}{r}-0.006 \\
(0.057)\end{array}$ & $\begin{array}{l}3.132 \text { ** } \\
(1.569)\end{array}$ & $\begin{array}{r}0.047 \\
(0.032)\end{array}$ & $\begin{array}{r}-0.076 \\
(0.048)\end{array}$ & $\begin{array}{l}-0.098 * * \\
(0.046)\end{array}$ & $\begin{array}{c}-0.114 * \\
(0.066)\end{array}$ & $\begin{array}{l}3.068 * \\
(1.66)\end{array}$ \\
\hline $\mathrm{N}$ & 1001 & 989 & 989 & 989 & 1001 & 1000 & 977 & 977 & 978 & 1000 \\
\hline
\end{tabular}

Notes: ${ }^{*} \mathrm{p}<0.10,{ }^{* *} \mathrm{p}<0.05,{ }^{* * *} \mathrm{p}<0.01$. See Table 2 for details. 
Table 4. Effect of Texas Enterprise Zone Program on the Change in Aggregate Financial Outcomes: Alternative Control Group

\begin{tabular}{|c|c|c|c|c|c|c|c|c|c|c|c|}
\hline & $\begin{array}{c}\text { Median } \\
\text { Risk Score }\end{array}$ & $\begin{array}{c}\text { Prime Risk } \\
\text { Score } \\
\text { (Percent) }\end{array}$ & $\begin{array}{l}\text { Near Prime } \\
\text { Risk Score } \\
\text { (Percent) }\end{array}$ & $\begin{array}{c}\text { Sub-Prime } \\
\text { Risk Score } \\
\text { (Percent) }\end{array}$ & $\begin{array}{c}\text { Chapter } 7 \\
\text { Bankruptcy } \\
\text { (Percent) }\end{array}$ & $\begin{array}{c}\text { Chapter } 13 \\
\text { Bankruptcy } \\
\text { (Percent) }\end{array}$ & $\begin{array}{c}\text { Median } \\
\text { Number of } \\
\text { Credit } \\
\text { Inquiries } \\
\text { (Past } 3 \\
\text { Months) }\end{array}$ & $\begin{array}{c}\text { Median } \\
\text { Number of } \\
\text { Credit } \\
\text { Inquiries } \\
\text { (Past 12 } \\
\text { Months) }\end{array}$ & $\begin{array}{c}\text { Median } \\
\text { Number of } \\
\text { New } \\
\text { Accounts } \\
\text { (Past } 6 \\
\text { Months) }\end{array}$ & $\begin{array}{c}\text { Median } \\
\text { Number of } \\
\text { New } \\
\text { Revolving } \\
\text { Accounts } \\
\text { (Past } 6 \\
\text { Months) }\end{array}$ & $\begin{array}{c}\text { Median } \\
\text { Number of } \\
\text { New } \\
\text { Accounts } \\
\text { (Past 12 } \\
\text { Months) }\end{array}$ \\
\hline \multicolumn{12}{|c|}{ I. $\Delta(2006: Q 4-2002: Q 4)$} \\
\hline TX EZ (1 = Yes) & $\begin{array}{r}4.016 \\
(10.95)\end{array}$ & $\begin{array}{r}0.002 \\
(0.030)\end{array}$ & $\begin{array}{r}-0.009 \\
(0.023)\end{array}$ & $\begin{array}{r}0.008 \\
(0.030)\end{array}$ & $\begin{array}{r}-0.008 \\
(0.010)\end{array}$ & $\begin{array}{l}0.013 \text { *** } \\
(0.004)\end{array}$ & $\begin{array}{r}0.497 \\
(0.808)\end{array}$ & $\begin{array}{r}0.504 \\
(0.933)\end{array}$ & $\begin{array}{r}0.010 \\
(0.043)\end{array}$ & $\begin{array}{r}-2.379 \\
(1.953)\end{array}$ & $\begin{array}{r}-0.001 \\
(0.253)\end{array}$ \\
\hline $\mathrm{N}$ & 834 & 834 & 834 & 834 & 834 & 834 & 834 & 834 & 834 & 834 & 834 \\
\hline \multicolumn{12}{|c|}{ II. $\Delta(2009: Q 4-2002: Q 4)$} \\
\hline TX EZ (1 = Yes) & $\begin{array}{l}13.219 \\
(12.00)\end{array}$ & $\begin{array}{r}0.022 \\
(0.038)\end{array}$ & $\begin{array}{r}-0.008 \\
(0.018)\end{array}$ & $\begin{array}{r}-0.014 \\
(0.039)\end{array}$ & $\begin{array}{r}0.002 \\
(0.010)\end{array}$ & $\begin{array}{l}0.012 * * \\
(0.005)\end{array}$ & $\begin{array}{r}1.528 \\
(2.421)\end{array}$ & $\begin{array}{r}1.579 \\
(2.402)\end{array}$ & $\begin{array}{r}-0.009 \\
(0.021)\end{array}$ & $\begin{array}{r}-2.046 \\
(1.562)\end{array}$ & $\begin{array}{r}0.060 \\
(0.178)\end{array}$ \\
\hline $\mathrm{N}$ & 833 & 833 & 833 & 833 & 833 & 833 & 833 & 833 & 833 & 833 & 833 \\
\hline
\end{tabular}

Notes: ${ }^{*} \mathrm{p}<0.10,{ }^{* *} \mathrm{p}<0.05,{ }^{* * *} \mathrm{p}<0.01$. Sample restricted to Census block groups with a poverty rate between 0.20 and 0.22 in 2000 and 0.18 and 0.20 in 2000 unless the block group borders at last one other block group with a poverty rate 0.20 or higher. Number of EZs is 445 in Panels I and II. Number of non-EZs is 389 and 388 in Panels I and II, respectively. Estimation is by OLS, weighted by number of individuals in the block group. Covariates include all variables listed in Table A1 in the appendix. Standard errors are clustered at the county level. Data sources: Federal Reserve Bank of New York Consumer Credit Panel/Equifax and 2000 Decennial Census. 
Table 5. Effect of Texas Enterprise Zone Program on the Change in Aggregate Financial Outcomes by Type: Alternative Control Group

\begin{tabular}{|c|c|c|c|c|c|c|c|c|c|c|}
\hline & \multicolumn{5}{|c|}{$\Delta(2006: Q 4-2002: Q 4)$} & \multicolumn{5}{|c|}{$\Delta(2009: Q 4-2002: Q 4)$} \\
\hline & $\begin{array}{c}\text { Borrowers } \\
\text { (Percent) }\end{array}$ & $\begin{array}{c}\text { Borrowers } \\
\text { Delinquent } \\
\text { (Percent) }\end{array}$ & $\begin{array}{c}\text { Borrowers } \\
\text { Severely } \\
\text { Delinquent } \\
\text { (Percent) }\end{array}$ & $\begin{array}{c}\text { Balance } \\
\text { Delinquent } \\
\text { (Percent) }\end{array}$ & $\begin{array}{c}\text { Median } \\
\text { Balance } \\
\text { (Dollars) }\end{array}$ & $\begin{array}{c}\text { Borrowers } \\
\text { (Percent) }\end{array}$ & $\begin{array}{c}\text { Borrowers } \\
\text { Delinquent } \\
\text { (Percent) }\end{array}$ & $\begin{array}{c}\text { Borrowers } \\
\text { Severely } \\
\text { Delinquent } \\
\text { (Percent) }\end{array}$ & $\begin{array}{c}\text { Balance } \\
\text { Delinquent } \\
\text { (Percent) }\end{array}$ & $\begin{array}{l}\text { Median } \\
\text { Balance } \\
\text { (Dollars) }\end{array}$ \\
\hline \multicolumn{11}{|l|}{ I. Auto Loans } \\
\hline TX EZ (1 = Yes) & $\begin{array}{r}-0.013 \\
(0.023)\end{array}$ & $\begin{array}{c}0.069 * \\
(0.036)\end{array}$ & $\begin{array}{r}0.007 \\
(0.033)\end{array}$ & $\begin{array}{r}0.025 \\
(0.023)\end{array}$ & $\begin{array}{r}26.43 \\
(63.25)\end{array}$ & $\begin{array}{r}0.002 \\
(0.029)\end{array}$ & $\begin{array}{r}-0.005 \\
(0.039)\end{array}$ & $\begin{array}{r}-0.006 \\
(0.027)\end{array}$ & $\begin{array}{r}-0.007 \\
(0.027)\end{array}$ & $\begin{array}{r}-11.76 \\
(113.0)\end{array}$ \\
\hline $\mathrm{N}$ & 834 & 822 & 822 & 822 & 834 & 833 & 824 & 824 & 824 & 833 \\
\hline \multicolumn{11}{|l|}{ II. Bank Cards } \\
\hline TX EZ (1 = Yes) & $\begin{array}{r}0.022 \\
(0.027)\end{array}$ & $\begin{array}{r}-0.027 \\
(0.031)\end{array}$ & $\begin{array}{r}-0.030 \\
(0.033)\end{array}$ & $\begin{array}{r}-0.030 \\
(0.056)\end{array}$ & $\begin{array}{r}-1.23 \\
(88.05)\end{array}$ & $\begin{array}{r}0.006 \\
(0.024)\end{array}$ & $\begin{array}{l}-0.064 * * \\
(0.029)\end{array}$ & $\begin{array}{r}-0.045 \\
(0.034)\end{array}$ & $\begin{array}{r}0.011 \\
(0.041)\end{array}$ & $\begin{array}{r}11.13 \\
(99.55)\end{array}$ \\
\hline $\mathrm{N}$ & 834 & 831 & 831 & 831 & 834 & 833 & 829 & 829 & 829 & 833 \\
\hline \multicolumn{11}{|c|}{ III. Mortgage Loans } \\
\hline TX EZ (1 = Yes) & $\begin{array}{r}-0.008 \\
(0.016)\end{array}$ & $\begin{array}{r}-0.005 \\
(0.052)\end{array}$ & $\begin{array}{r}-0.004 \\
(0.029)\end{array}$ & $\begin{array}{l}-0.008 \\
(0.056)\end{array}$ & $\begin{array}{r}350.99 \\
(230.7)\end{array}$ & $\begin{array}{r}-0.017 \\
(0.017)\end{array}$ & $\begin{array}{r}0.053 \\
(0.055)\end{array}$ & $\begin{array}{r}0.005 \\
(0.043)\end{array}$ & $\begin{array}{r}0.069 \\
(0.058)\end{array}$ & $\begin{array}{r}115.22 \\
(227.7)\end{array}$ \\
\hline $\mathrm{N}$ & 834 & 709 & 709 & 709 & 834 & 833 & 713 & 713 & 713 & 833 \\
\hline \multicolumn{11}{|l|}{ IV. Retail Loans } \\
\hline TX EZ (1 = Yes) & $\begin{array}{r}0.001 \\
(0.021)\end{array}$ & $\begin{array}{l}-0.087 * \\
(0.049)\end{array}$ & $\begin{array}{l}-0.102 * * \\
(0.045)\end{array}$ & $\begin{array}{r}-0.051 \\
(0.068)\end{array}$ & $\begin{array}{r}2.513 \\
(1.752)\end{array}$ & $\begin{array}{r}0.021 \\
(0.028)\end{array}$ & $\begin{array}{l}-0.099 * \\
(0.056)\end{array}$ & $\begin{array}{l}-0.116 * * \\
(0.051)\end{array}$ & $\begin{array}{c}-0.114 * \\
(0.067)\end{array}$ & $\begin{array}{l}2.988 * \\
(1.61)\end{array}$ \\
\hline $\mathrm{N}$ & 834 & 822 & 822 & 822 & 834 & 833 & 813 & 813 & 814 & 833 \\
\hline
\end{tabular}

Notes: ${ }^{*} \mathrm{p}<0.10,{ }^{* *} \mathrm{p}<0.05,{ }^{* * *} \mathrm{p}<0.01$. See Table 4 for details. 
Table 6. Effect of Texas Enterprise Zone Program on the Change in Aggregate Financial Outcomes: Alternative Treatment Definition

\begin{tabular}{|c|c|c|c|c|c|c|c|c|c|c|}
\hline $\begin{array}{c}\text { Median } \\
\text { Risk Score }\end{array}$ & $\begin{array}{c}\text { Prime Risk } \\
\text { Score } \\
\text { (Percent) }\end{array}$ & $\begin{array}{c}\text { Near Prime } \\
\text { Risk Score } \\
\text { (Percent) }\end{array}$ & $\begin{array}{c}\text { Sub-Prime } \\
\text { Risk Score } \\
\text { (Percent) }\end{array}$ & $\begin{array}{c}\text { Chapter } 7 \\
\text { Bankruptcy } \\
\text { (Percent) }\end{array}$ & $\begin{array}{c}\text { Chapter } 13 \\
\text { Bankruptcy } \\
\text { (Percent) }\end{array}$ & $\begin{array}{c}\text { Median } \\
\text { Number of } \\
\text { Credit } \\
\text { Inquiries } \\
\text { (Past } 3 \\
\text { Months) }\end{array}$ & $\begin{array}{c}\text { Median } \\
\text { Number of } \\
\text { Credit } \\
\text { Inquiries } \\
\text { (Past 12 } \\
\text { Months) }\end{array}$ & $\begin{array}{c}\text { Median } \\
\text { Number of } \\
\text { New } \\
\text { Accounts } \\
\text { (Past } 6 \\
\text { Months) }\end{array}$ & $\begin{array}{c}\text { Median } \\
\text { Number of } \\
\text { New } \\
\text { Revolving } \\
\text { Accounts } \\
\text { (Past } 6 \\
\text { Months) }\end{array}$ & $\begin{array}{c}\text { Median } \\
\text { Number of } \\
\text { New } \\
\text { Accounts } \\
\text { (Past 12 } \\
\text { Months) }\end{array}$ \\
\hline
\end{tabular}

\section{I. $\Delta$ (2006:Q4-2002:Q4)}

$\begin{array}{crrrrrrrrrrr}\text { Border TX EZ } & 12.429 & 0.041 & -0.048 * & 0.007 & -0.014 & 0.008 & 0.179 & -0.527 & -0.033 & -2.684 & 0.021 \\ \quad(1=\text { Yes }) & (12.65) & (0.043) & (0.029) & (0.048) & (0.018) & (0.008) & (0.758) & (0.700) & (0.063) & (4.033) & (0.285) \\ \mathrm{N} & 220 & 220 & 220 & 220 & 220 & 220 & 220 & 220 & 220 & 220 & 220\end{array}$

\section{II. $\Delta(2009: Q 4-2002: Q 4)$}

\begin{tabular}{crrrrrrrrrrr} 
Border TX EZ & 3.342 & -0.034 & 0.049 & -0.015 & -0.018 & 0.017 & 0.497 & -0.172 & -0.034 & -1.547 & -0.376 \\
$\quad(1=$ Yes $)$ & $(15.01)$ & $(0.052)$ & $(0.043)$ & $(0.063)$ & $(0.018)$ & $(0.011)$ & $(1.43)$ & $(1.569)$ & $(0.078)$ & $(3.932)$ & $(0.247)$ \\
$\mathrm{N}$ & 219 & 219 & 219 & 219 & 219 & 219 & 219 & 219 & 219 & 219 & 219 \\
\hline
\end{tabular}

Notes: ${ }^{*} \mathrm{p}<0.10,{ }^{* *} \mathrm{p}<0.05,{ }^{* * *} \mathrm{p}<0.01$. Sample restricted to Census block groups with a poverty rate between 0.15 and 0.20 in 2000 . Treatment group is defined as block groups with a maximum poverty rate amongst its contiguous neighboring block groups between 0.20 and 0.22 . Control group is defined as block groups with a maximum poverty rate amongst its contiguous neighboring block groups between 0.18 and 0.20 . Number of treated is 99 in Panels I and II. Number of controls is 121 and 120 in Panels I and II, respectively. Estimation is by OLS, weighted by number of individuals in the block group. Covariates include all variables listed in Table A1 in the appendix, plus the block group's own poverty rate. Standard errors are clustered at the county level. Data sources: Federal Reserve Bank of New York Consumer Credit Panel/Equifax and 2000 Decennial Census. 
Table 7. Effect of Texas Enterprise Zone Program on the Change in Aggregate Financial Outcomes by Type: Alternative Treatment Definition

\begin{tabular}{|c|c|c|c|c|c|c|c|c|c|c|}
\hline & \multicolumn{5}{|c|}{$\Delta(2006: Q 4-2002: Q 4)$} & \multicolumn{5}{|c|}{$\Delta(2009: Q 4-2002: Q 4)$} \\
\hline & $\begin{array}{c}\text { Borrowers } \\
\text { (Percent) }\end{array}$ & $\begin{array}{c}\text { Borrowers } \\
\text { Delinquent } \\
\text { (Percent) }\end{array}$ & $\begin{array}{c}\text { Borrowers } \\
\text { Severely } \\
\text { Delinquent } \\
\text { (Percent) }\end{array}$ & $\begin{array}{c}\text { Balance } \\
\text { Delinquent } \\
\text { (Percent) }\end{array}$ & $\begin{array}{l}\text { Median } \\
\text { Balance } \\
\text { (Dollars) }\end{array}$ & $\begin{array}{c}\text { Borrowers } \\
\text { (Percent) }\end{array}$ & $\begin{array}{c}\text { Borrowers } \\
\text { Delinquent } \\
\text { (Percent) }\end{array}$ & $\begin{array}{l}\text { Borrowers } \\
\text { Severely } \\
\text { Delinquent } \\
\text { (Percent) }\end{array}$ & $\begin{array}{c}\text { Balance } \\
\text { Delinquent } \\
\text { (Percent) }\end{array}$ & $\begin{array}{c}\text { Median } \\
\text { Balance } \\
\text { (Dollars) }\end{array}$ \\
\hline \multicolumn{11}{|l|}{ I. Auto Loans } \\
\hline $\begin{array}{l}\text { Border TX EZ } \\
\quad(1=\text { Yes })\end{array}$ & $\begin{array}{r}0.064 \\
(0.045)\end{array}$ & $\begin{array}{r}0.068 \\
(0.064)\end{array}$ & $\begin{array}{r}0.057 \\
(0.068)\end{array}$ & $\begin{array}{r}0.004 \\
(0.034)\end{array}$ & $\begin{array}{r}91.52 \\
(111.3)\end{array}$ & $\begin{array}{r}-0.038 \\
(0.054)\end{array}$ & $\begin{array}{r}0.088 \\
(0.057)\end{array}$ & $\begin{array}{r}-0.001 \\
(0.063)\end{array}$ & $\begin{array}{l}0.090 \text { ** } \\
(0.042)\end{array}$ & $\begin{array}{r}-2117.3 \\
(1971)\end{array}$ \\
\hline $\mathrm{N}$ & 220 & 217 & 217 & 217 & 220 & 219 & 217 & 217 & 217 & 219 \\
\hline \multicolumn{11}{|c|}{ II. Bank Cards } \\
\hline $\begin{array}{c}\text { Border TX EZ } \\
\quad(1=\text { Yes })\end{array}$ & $\begin{array}{l}-0.039 \\
(0.04)\end{array}$ & $\begin{array}{r}-0.003 \\
(0.057)\end{array}$ & $\begin{array}{r}0.030 \\
(0.055)\end{array}$ & $\begin{array}{r}0.082 \\
(0.102)\end{array}$ & $\begin{array}{r}77.75 \\
(141.8)\end{array}$ & $\begin{array}{r}-0.033 \\
(0.061)\end{array}$ & $\begin{array}{r}0.023 \\
(0.091)\end{array}$ & $\begin{array}{r}0.058 \\
(0.083)\end{array}$ & $\begin{array}{r}0.115 \\
(0.108)\end{array}$ & $\begin{array}{r}-43.83 \\
(90.52)\end{array}$ \\
\hline $\mathrm{N}$ & 220 & 219 & 219 & 219 & 220 & 219 & 217 & 217 & 217 & 219 \\
\hline \multicolumn{11}{|c|}{ III. Mortgage Loans } \\
\hline $\begin{array}{c}\text { Border TX EZ } \\
\quad(1=\text { Yes })\end{array}$ & $\begin{array}{r}-0.046 \\
(0.032)\end{array}$ & $\begin{array}{r}0.008 \\
(0.099)\end{array}$ & $\begin{array}{r}0.031 \\
(0.04)\end{array}$ & $\begin{array}{r}-0.025 \\
(0.110)\end{array}$ & $\begin{array}{r}-13.64 \\
(16.98)\end{array}$ & $\begin{array}{r}-0.043 \\
(0.027)\end{array}$ & $\begin{array}{r}-0.041 \\
(0.121)\end{array}$ & $\begin{array}{r}-0.005 \\
(0.076)\end{array}$ & $\begin{array}{r}-0.135 \\
(0.160)\end{array}$ & \\
\hline $\mathrm{N}$ & 220 & 202 & 202 & 202 & 220 & 219 & 204 & 204 & 204 & \\
\hline \multicolumn{11}{|c|}{ IV. Retail Loans } \\
\hline $\begin{array}{l}\text { Border TX EZ } \\
\quad(1=\text { Yes })\end{array}$ & $\begin{array}{r}-0.056 \\
(0.038)\end{array}$ & $\begin{array}{r}-0.075 \\
(0.104)\end{array}$ & $\begin{array}{r}-0.053 \\
(0.087)\end{array}$ & $\begin{array}{r}-0.107 \\
(0.162)\end{array}$ & $\begin{array}{r}-0.386 \\
(0.519)\end{array}$ & $\begin{array}{r}-0.049 \\
(0.031)\end{array}$ & $\begin{array}{r}-0.080 \\
(0.104)\end{array}$ & $\begin{array}{r}-0.048 \\
(0.079)\end{array}$ & $\begin{array}{r}0.066 \\
(0.146)\end{array}$ & $\begin{array}{r}0.772 \\
(1.62)\end{array}$ \\
\hline $\mathrm{N}$ & 220 & 216 & 216 & 216 & 220 & 219 & 213 & 213 & 213 & 219 \\
\hline
\end{tabular}

Notes: ${ }^{*} \mathrm{p}<0.10,{ }^{* *} \mathrm{p}<0.05,{ }^{* * *} \mathrm{p}<0.01$. See Table 6 for details. 

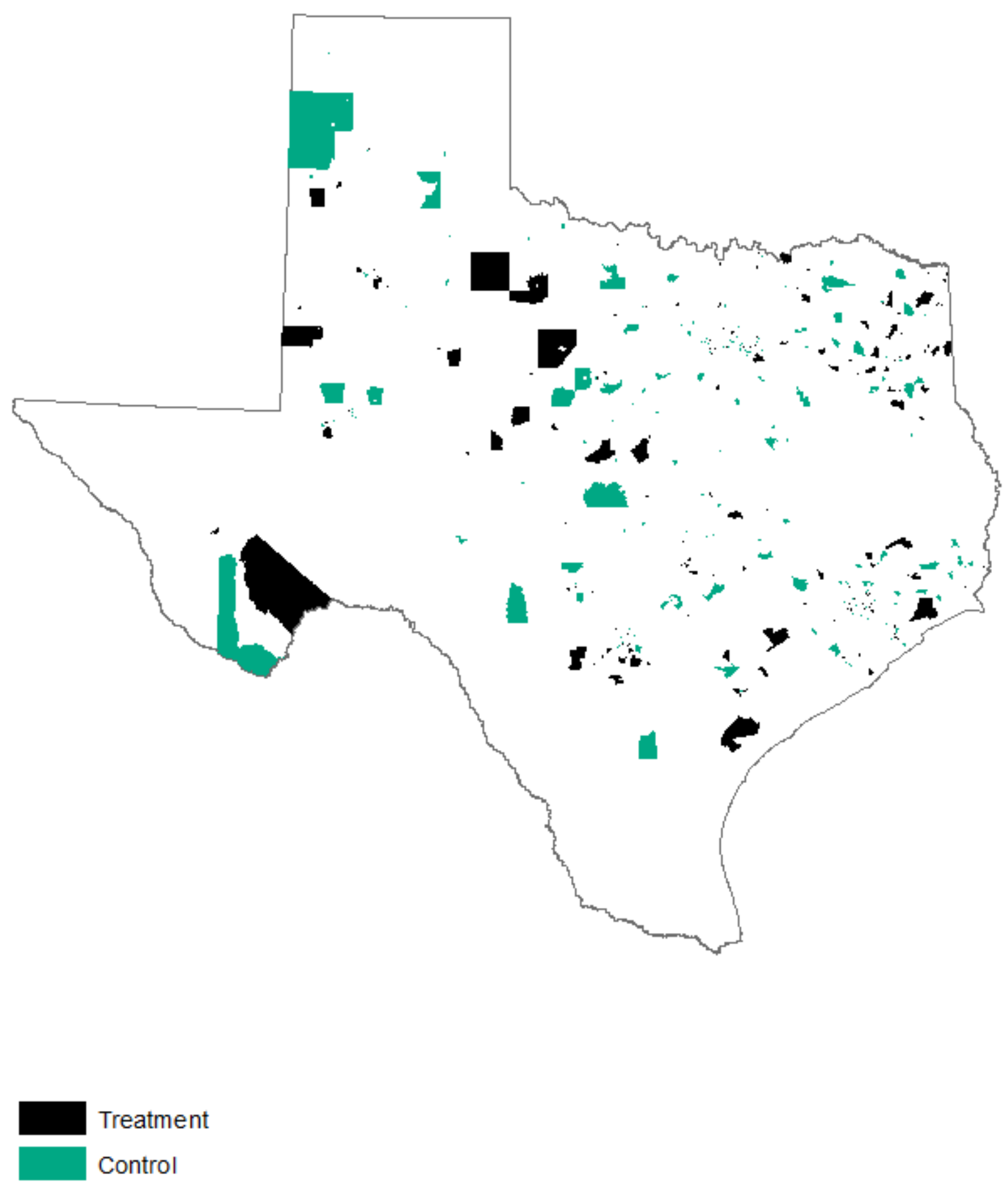

Figure A1. Map of Treatment and Alternative Control Groups.

Notes: Treatment group consists of Census block groups with a poverty rate between 0.20 and 0.22 . Control group consists of Census block groups with a poverty rate between 0.18 and 0.20 that do not border a block group with a poverty rate exceeding 0.20 . 


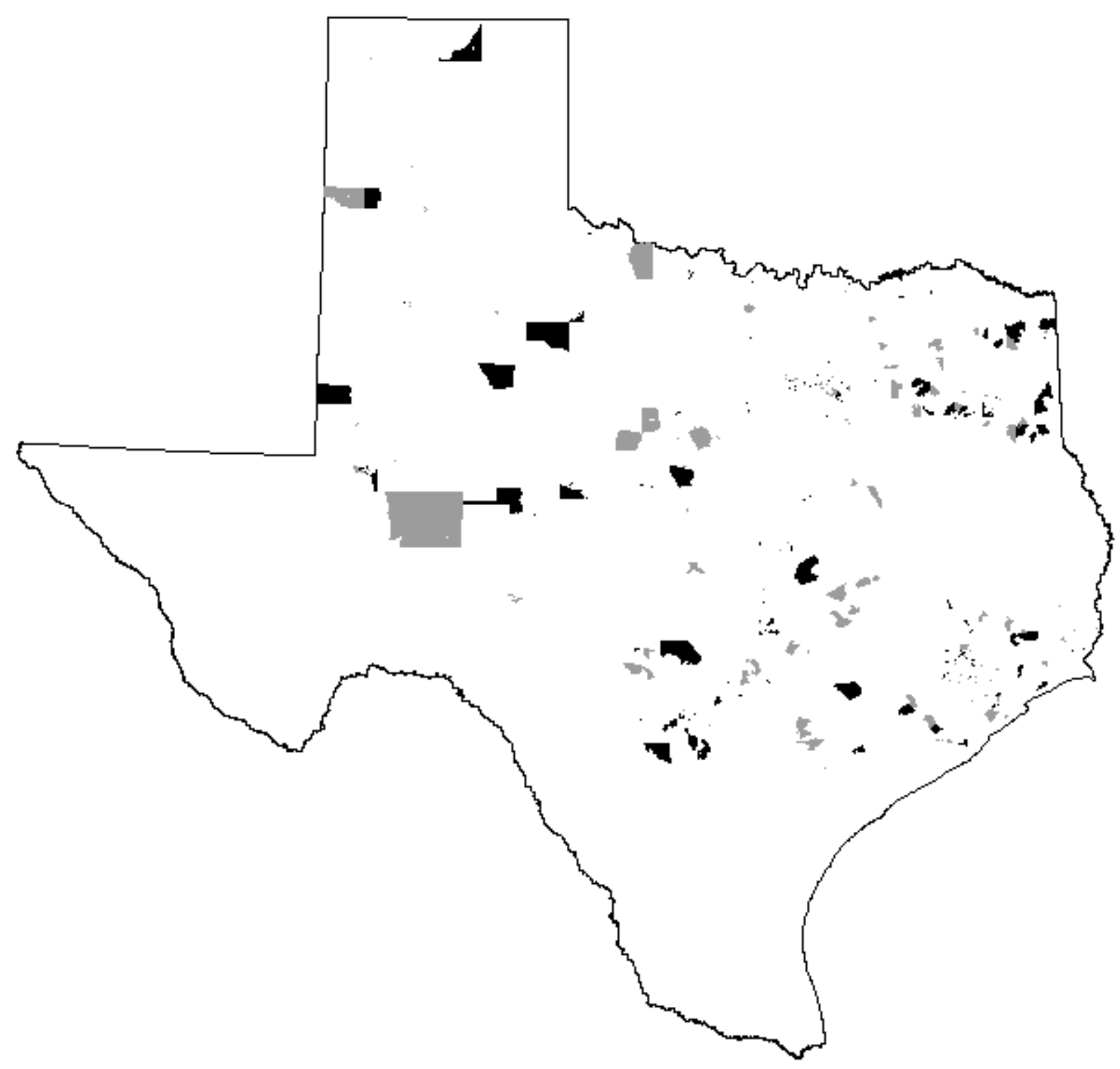

Max Neigh bor Poverty between $18-20 \%$

Max Neighbor Poverty between 20-22\%

Figure A2. Map of Alternative Treatment and Control Groups.

Notes: Treatment group consists of Census block groups with a poverty rate between 0.15 and 0.20 and the maximum poverty rate among its contiguous neighbors between 0.20 and 0.22 . Control group consists of block groups with a poverty rate between 0.15 and 0.20 and the maximum poverty rate among its contiguous neighbors between 0.18 and 0.20 . 
Table A1. Summary Statistics: Census Block Characteristics.

\begin{tabular}{|c|c|c|c|c|c|c|c|c|}
\hline & \multicolumn{4}{|c|}{$\mathrm{BW}=0.02$} & \multicolumn{4}{|c|}{ Full Sample } \\
\hline & \multicolumn{2}{|c|}{ EZs } & \multicolumn{2}{|c|}{ Non-EZs } & \multicolumn{2}{|c|}{ EZs } & \multicolumn{2}{|c|}{ Non-EZs } \\
\hline & Mean & SD & Mean & SD & Mean & SD & Mean & SD \\
\hline Poverty Rate & 0.21 & 0.01 & 0.19 & 0.01 & 0.31 & 0.11 & 0.08 & 0.05 \\
\hline Population & 1658.69 & 993.30 & 1631.97 & 937.67 & 1653.06 & 1124.57 & 2171.47 & 1657.10 \\
\hline Population, Male & 833.11 & 519.19 & 807.43 & 478.17 & 830.92 & 620.13 & 1075.91 & 870.61 \\
\hline Population, Aged 18-64 & 1039.67 & 677.96 & 1023.22 & 654.20 & 1041.68 & 841.15 & 1391.30 & 1098.91 \\
\hline Population, White & 919.52 & 522.27 & 957.16 & 540.97 & 809.28 & 673.58 & 1642.45 & 1296.83 \\
\hline Population, Black & 293.56 & 426.65 & 310.94 & 461.16 & 397.03 & 550.75 & 212.43 & 415.09 \\
\hline Population, Hispanic & 698.73 & 653.62 & 551.68 & 540.21 & 746.94 & 783.57 & 388.97 & 459.91 \\
\hline Population, Male, Educ 2 & 10.78 & 15.75 & 8.85 & 12.37 & 12.96 & 19.33 & 3.86 & 8.22 \\
\hline Population, Male, Educ 3 & 29.62 & 41.99 & 22.44 & 26.23 & 34.42 & 46.39 & 10.73 & 18.13 \\
\hline Population, Male, Educ 4 & 24.68 & 22.22 & 20.80 & 18.67 & 24.94 & 28.03 & 11.89 & 15.59 \\
\hline Population, Male, Educ 5 & 25.65 & 28.80 & 20.70 & 19.45 & 25.90 & 32.26 & 12.29 & 17.12 \\
\hline Population, Male, Educ 6 & 16.81 & 16.29 & 17.79 & 17.80 & 18.78 & 20.67 & 12.36 & 15.90 \\
\hline Population, Male, Educ 7 & 17.87 & 19.22 & 16.71 & 14.80 & 19.00 & 22.12 & 12.07 & 16.37 \\
\hline Population, Male, Educ 8 & 24.12 & 23.05 & 22.00 & 20.87 & 25.68 & 28.49 & 17.64 & 18.91 \\
\hline Population, Male, Educ 9 & 121.43 & 86.43 & 123.13 & 79.48 & 110.19 & 98.51 & 133.58 & 104.94 \\
\hline Population, Male, Educ 10 & 30.09 & 25.19 & 30.80 & 25.52 & 24.28 & 26.90 & 46.84 & 44.72 \\
\hline Population, Male, Educ 11 & 63.55 & 46.86 & 69.54 & 56.71 & 51.33 & 53.46 & 112.98 & 96.74 \\
\hline Population, Male, Educ 12 & 18.52 & 17.62 & 21.12 & 22.44 & 15.06 & 18.16 & 41.94 & 44.09 \\
\hline Population, Male, Educ 13 & 49.43 & 64.18 & 54.39 & 78.76 & 36.76 & 54.68 & 156.64 & 192.32 \\
\hline Population, Male, Educ 14 & 17.39 & 29.28 & 16.85 & 25.10 & 12.57 & 25.36 & 52.64 & 75.68 \\
\hline Population, Male, Educ 15 & 6.01 & 11.33 & 6.39 & 12.21 & 4.59 & 11.97 & 17.83 & 29.29 \\
\hline Population, Male, Educ 16 & 3.84 & 10.91 & 3.89 & 9.66 & 3.54 & 12.58 & 10.24 & 19.35 \\
\hline Population, Female, Educ 2 & 9.35 & 11.82 & 8.15 & 11.56 & 11.32 & 14.81 & 3.89 & 7.66 \\
\hline Population, Female, Educ 3 & 26.92 & 32.26 & 20.82 & 22.74 & 29.08 & 35.60 & 10.19 & 16.31 \\
\hline Population, Female, Educ 4 & 24.53 & 20.28 & 22.64 & 19.26 & 25.65 & 22.03 & 13.69 & 17.65 \\
\hline Population, Female, Educ 5 & 25.10 & 23.71 & 21.30 & 17.48 & 25.23 & 24.40 & 12.53 & 14.92 \\
\hline Population, Female, Educ 6 & 19.56 & 15.81 & 20.34 & 17.52 & 20.55 & 17.92 & 14.39 & 16.53 \\
\hline Population, Female, Educ 7 & 18.31 & 14.97 & 19.89 & 17.19 & 20.91 & 18.85 & 14.19 & 16.60 \\
\hline Population, Female, Educ 8 & 22.70 & 22.92 & 23.45 & 22.11 & 23.84 & 23.61 & 19.77 & 20.37 \\
\hline Population, Female, Educ 9 & 133.58 & 77.45 & 140.05 & 82.23 & 123.29 & 84.70 & 169.50 & 114.05 \\
\hline Population, Female, Educ 10 & 34.64 & 27.24 & 43.23 & 35.79 & 29.87 & 27.62 & 63.64 & 52.77 \\
\hline Population, Female, Educ 11 & 61.80 & 47.72 & 71.54 & 54.47 & 51.79 & 47.04 & 120.95 & 100.08 \\
\hline Population, Female, Educ 12 & 20.96 & 21.26 & 24.23 & 23.55 & 16.28 & 18.69 & 46.08 & 43.34 \\
\hline Population, Female, Educ 13 & 49.37 & 57.66 & 53.21 & 61.11 & 35.39 & 49.32 & 149.42 & 175.41 \\
\hline Population, Female, Educ 14 & 15.72 & 20.00 & 16.07 & 19.70 & 12.12 & 20.77 & 45.39 & 55.68 \\
\hline Population, Female, Educ 15 & 4.58 & 10.22 & 4.21 & 7.00 & 3.86 & 9.99 & 9.88 & 16.02 \\
\hline Population, Female, Educ 16 & 1.70 & 4.57 & 1.49 & 4.37 & 1.75 & 6.95 & 4.23 & 8.56 \\
\hline Median HH Income & 30908.80 & 6724.30 & 32268.00 & 6788.36 & 25259.60 & 8301.65 & 53989.40 & 23994.00 \\
\hline Housing Units, Vacant & 57.76 & 58.40 & 65.69 & 66.28 & 59.48 & 60.10 & 58.87 & 79.41 \\
\hline Housing Units, Owner-Occupied & 265.86 & 170.52 & 298.18 & 186.72 & 214.24 & 156.46 & 538.12 & 443.24 \\
\hline Housing Units, Rental & 327.43 & 360.97 & 307.05 & 377.92 & 348.43 & 398.86 & 254.72 & 389.89 \\
\hline Housing Units, Median Rooms & 4.53 & 0.77 & 4.67 & 0.74 & 4.34 & 0.83 & 5.57 & 1.19 \\
\hline Housing Units, Median Age & 1968.41 & 11.92 & 1969.48 & 11.86 & 1964.05 & 61.37 & 1977.74 & 12.74 \\
\hline Housing Units, Median Value & 59562.90 & 31106.30 & 62699.90 & 37849.70 & 53492.30 & 44596.90 & 107098.00 & 77682.90 \\
\hline Population, Male Aged 16+, In LF & 434.35 & 298.25 & 427.46 & 295.64 & 399.37 & 331.75 & 632.62 & 560.43 \\
\hline Population, Female Aged 16+, In LF & 336.95 & 221.71 & 349.01 & 240.93 & 317.81 & 245.80 & 517.85 & 396.05 \\
\hline
\end{tabular}

Notes: Weighted by number of individuals in the block group. LF = labor force. $\mathrm{N}=445$ (555) for EZs (non-EZs) when BW = 0.02. $\mathrm{N}=3006$ (8680) for EZs (non-EZs) in full sample. Data sources: 2000 Decennial Census. 
Table A2. Summary Statistics: 2002:Q4-2006:Q4.

\begin{tabular}{|c|c|c|c|c|c|c|c|c|c|c|c|c|}
\hline & \multicolumn{6}{|c|}{$\mathrm{BW}=\mathbf{0 . 0 2}$} & \multicolumn{6}{|c|}{ Full Sample } \\
\hline & \multicolumn{3}{|c|}{ EZs } & \multicolumn{3}{|c|}{ Non-EZs } & \multicolumn{3}{|c|}{ EZs } & \multicolumn{3}{|c|}{ Non-EZs } \\
\hline & $\mathbf{N}$ & Mean & SD & $\mathbf{N}$ & Mean & SD & $\mathbf{N}$ & Mean & SD & $\mathbf{N}$ & Mean & SD \\
\hline$\Delta$ Median Risk Score & 445 & 1.70 & 30.04 & 556 & 1.57 & 28.31 & 3012 & 3.49 & 28.57 & 8678 & 2.25 & 24.67 \\
\hline$\Delta$ Prime Risk Score (\%) & 445 & 0.01 & 0.09 & 556 & 0.01 & 0.08 & 3012 & 0.00 & 0.09 & 8678 & 0.00 & 0.07 \\
\hline$\Delta$ Near PrimeRisk Score (\%) & 445 & 0.00 & 0.08 & 556 & 0.00 & 0.07 & 3012 & 0.00 & 0.08 & 8678 & -0.01 & 0.06 \\
\hline$\Delta$ Sub-Prime Risk Score (\%) & 445 & 0.00 & 0.09 & 556 & 0.00 & 0.09 & 3012 & 0.00 & 0.10 & 8678 & 0.00 & 0.08 \\
\hline$\Delta$ Chapter 7 Bankruptcy (\%) & 445 & 0.00 & 0.03 & 556 & 0.00 & 0.03 & 3012 & 0.00 & 0.02 & 8678 & 0.01 & 0.03 \\
\hline$\Delta$ Chapter 13 Bankruptcy $(\%)$ & 445 & 0.00 & 0.02 & 556 & 0.00 & 0.02 & 3012 & 0.00 & 0.02 & 8678 & 0.00 & 0.02 \\
\hline$\Delta$ Median Number of New Inquiries (Past 3 Months) & 445 & 0.23 & 4.40 & 556 & -0.38 & 5.88 & 3012 & 0.20 & 5.57 & 8678 & -0.20 & 6.09 \\
\hline$\Delta$ Median Number of New Inquiries (Past 12 Months) & 445 & 0.29 & 4.52 & 556 & -0.26 & 5.85 & 3012 & 0.28 & 5.57 & 8678 & -0.15 & 6.03 \\
\hline$\Delta$ Median Number of New Accounts (Past 6 Months) & 445 & 0.01 & 0.20 & 556 & 0.01 & 0.18 & 3012 & 0.07 & 2.31 & 8678 & -0.01 & 0.24 \\
\hline$\Delta$ Median Number of New Revolving Accounts (Past 6 Months) & 445 & 1.46 & 12.70 & 556 & 0.47 & 6.16 & 3012 & 2.76 & 16.66 & 8678 & 0.09 & 2.74 \\
\hline$\Delta$ Median Number of New Accounts (Past 12 Months) & 445 & -0.05 & 0.65 & 556 & -0.02 & 0.60 & 3012 & 0.09 & 2.38 & 8678 & -0.07 & 0.57 \\
\hline \multicolumn{13}{|l|}{ Auto Loans } \\
\hline$\Delta$ Borrowers $(\%)$ & 445 & 0.00 & 0.09 & 556 & 0.01 & 0.08 & 3012 & 0.01 & 0.08 & 8678 & 0.02 & 0.08 \\
\hline$\Delta$ Borrowers Delinquent $(\%)$ & 442 & 0.03 & 0.15 & 543 & 0.02 & 0.13 & 2942 & 0.03 & 0.18 & 8610 & 0.01 & 0.10 \\
\hline$\Delta$ Borrowers Severely Delinquent (\%) & 442 & 0.03 & 0.12 & 543 & 0.02 & 0.11 & 2942 & 0.03 & 0.15 & 8610 & 0.02 & 0.08 \\
\hline$\Delta$ Balances Delinquent $(\%)$ & 442 & 0.01 & 0.08 & 543 & 0.01 & 0.06 & 2942 & 0.01 & 0.09 & 8610 & 0.01 & 0.05 \\
\hline$\Delta$ Median Balance & 445 & 8.69 & 594.43 & 556 & 16.85 & 446.41 & 3012 & 0.17 & 457.04 & 8678 & 66.98 & 810.93 \\
\hline \multicolumn{13}{|l|}{ Bank Cards } \\
\hline$\Delta$ Borrowers (\%) & 445 & -0.07 & 0.09 & 556 & -0.07 & 0.08 & 3012 & -0.07 & 0.09 & 8678 & -0.05 & 0.07 \\
\hline$\Delta$ Borrowers Delinquent (\%) & 445 & 0.02 & 0.14 & 553 & 0.01 & 0.12 & 2990 & 0.02 & 0.15 & 8659 & 0.01 & 0.09 \\
\hline$\Delta$ Borrowers Severely Delinquent (\%) & 445 & 0.02 & 0.14 & 553 & 0.02 & 0.12 & 2990 & 0.03 & 0.15 & 8659 & 0.02 & 0.09 \\
\hline$\Delta$ Balances Delinquent $(\%)$ & 445 & 0.04 & 0.19 & 553 & 0.03 & 0.18 & 2990 & 0.04 & 0.21 & 8659 & 0.02 & 0.13 \\
\hline$\Delta$ Median Balance & 445 & -82.83 & 274.95 & 556 & -94.41 & 306.07 & 3012 & -57.69 & 244.69 & 8678 & -118.06 & 465.56 \\
\hline \multicolumn{13}{|l|}{ Mortgage Loans } \\
\hline$\Delta$ Borrowers $(\%)$ & 445 & 0.01 & 0.05 & 556 & 0.01 & 0.06 & 3012 & 0.01 & 0.05 & 8678 & 0.01 & 0.07 \\
\hline$\Delta$ Borrowers Delinquent $(\%)$ & 379 & 0.00 & 0.21 & 481 & 0.01 & 0.18 & 2230 & 0.00 & 0.23 & 8291 & 0.00 & 0.11 \\
\hline$\Delta$ Borrowers Severely Delinquent (\%) & 379 & 0.01 & 0.11 & 481 & 0.00 & 0.09 & 2230 & 0.01 & 0.14 & 8291 & 0.00 & 0.06 \\
\hline$\Delta$ Balances Delinquent $(\%)$ & 379 & 0.01 & 0.22 & 481 & 0.01 & 0.19 & 2231 & 0.00 & 0.24 & 8292 & 0.00 & 0.13 \\
\hline$\Delta$ Median Balance & 445 & -0.59 & 311.42 & 556 & 91.24 & 2492.80 & 3012 & 40.23 & 1660.82 & 8678 & 71.23 & 8534.04 \\
\hline \multicolumn{13}{|l|}{ Retail Loans } \\
\hline$\Delta$ Borrowers $(\%)$ & 445 & -0.08 & 0.07 & 556 & -0.08 & 0.07 & 3012 & -0.08 & 0.08 & 8678 & -0.05 & 0.07 \\
\hline$\Delta$ Borrowers Delinquent (\%) & 438 & -0.07 & 0.21 & 551 & -0.08 & 0.18 & 2920 & -0.08 & 0.22 & 8612 & -0.05 & 0.14 \\
\hline$\Delta$ Borrowers Severely Delinquent (\%) & 438 & -0.06 & 0.20 & 551 & -0.07 & 0.17 & 2920 & -0.08 & 0.21 & 8612 & -0.05 & 0.13 \\
\hline$\Delta$ Balances Delinquent $(\%)$ & 438 & -0.11 & 0.29 & 551 & -0.10 & 0.25 & 2920 & -0.11 & 0.29 & 8612 & -0.09 & 0.21 \\
\hline$\Delta$ Median Balance & 445 & -0.30 & 9.30 & 556 & -0.93 & 36.82 & 3012 & -0.40 & 15.96 & 8678 & -0.30 & 12.89 \\
\hline
\end{tabular}

Notes: Weighted by number of individuals in the block group. Data sources: Federal Reserve Bank of New York Consumer Credit Panel/Equifax. 
Table A3. Summary Statistics: 2002:Q4-2009:Q4.

\begin{tabular}{|c|c|c|c|c|c|c|c|c|c|c|c|c|}
\hline & \multicolumn{6}{|c|}{$\mathrm{BW}=\mathbf{0 . 0 2}$} & \multicolumn{6}{|c|}{ Full Sample } \\
\hline & \multicolumn{3}{|c|}{ EZs } & \multicolumn{3}{|c|}{ Non-EZs } & \multicolumn{3}{|c|}{ EZs } & \multicolumn{3}{|c|}{ Non-EZs } \\
\hline & $\mathbf{N}$ & Mean & SD & $\mathbf{N}$ & Mean & SD & $\mathbf{N}$ & Mean & SD & $\mathbf{N}$ & Mean & SD \\
\hline$\Delta$ Median Risk Score & 445 & 13.00 & 34.29 & 555 & 14.05 & 33.79 & 3006 & 13.26 & 33.72 & 8680 & 10.38 & 28.49 \\
\hline$\Delta$ Prime Risk Score (\%) & 445 & 0.03 & 0.10 & 555 & 0.04 & 0.12 & 3006 & 0.03 & 0.10 & 8680 & 0.02 & 0.09 \\
\hline$\Delta$ Near PrimeRisk Score (\%) & 445 & 0.01 & 0.08 & 555 & 0.00 & 0.08 & 3006 & 0.01 & 0.09 & 8680 & 0.00 & 0.07 \\
\hline$\Delta$ Sub-Prime Risk Score (\%) & 445 & -0.04 & 0.11 & 555 & -0.04 & 0.12 & 3006 & -0.04 & 0.12 & 8680 & -0.02 & 0.09 \\
\hline$\Delta$ Chapter 7 Bankruptcy (\%) & 445 & 0.00 & 0.03 & 555 & 0.00 & 0.03 & 3006 & 0.00 & 0.03 & 8680 & 0.00 & 0.03 \\
\hline$\Delta$ Chapter 13 Bankruptcy $(\%)$ & 445 & 0.00 & 0.02 & 555 & 0.00 & 0.02 & 3006 & 0.00 & 0.02 & 8680 & 0.00 & 0.02 \\
\hline$\Delta$ Median Number of New Inquiries (Past 3 Months) & 445 & -0.05 & 4.97 & 555 & -0.13 & 9.38 & 3006 & 0.05 & 6.83 & 8680 & -0.35 & 7.12 \\
\hline$\Delta$ Median Number of New Inquiries (Past 12 Months) & 445 & -0.17 & 4.98 & 555 & -0.27 & 9.30 & 3006 & -0.10 & 6.79 & 8680 & -0.39 & 7.04 \\
\hline$\Delta$ Median Number of New Accounts (Past 6 Months) & 445 & 0.00 & 0.17 & 555 & -0.01 & 0.13 & 3006 & 0.01 & 1.30 & 8680 & -0.02 & 0.18 \\
\hline$\Delta$ Median Number of New Revolving Accounts (Past 6 Months) & 445 & 0.75 & 10.93 & 555 & 0.89 & 8.60 & 3006 & 2.24 & 15.50 & 8680 & 0.16 & 3.87 \\
\hline$\Delta$ Median Number of New Accounts (Past 12 Months) & 445 & -0.27 & 0.56 & 555 & -0.25 & 0.54 & 3006 & -0.18 & 1.40 & 8680 & -0.47 & 0.55 \\
\hline \multicolumn{13}{|l|}{ Auto Loans } \\
\hline$\Delta$ Borrowers $(\%)$ & 445 & 0.03 & 0.09 & 555 & 0.03 & 0.11 & 3006 & 0.03 & 0.09 & 8680 & 0.02 & 0.09 \\
\hline$\Delta$ Borrowers Delinquent $(\%)$ & 442 & 0.06 & 0.18 & 545 & 0.06 & 0.17 & 2929 & 0.07 & 0.20 & 8608 & 0.05 & 0.11 \\
\hline$\Delta$ Borrowers Severely Delinquent (\%) & 442 & 0.07 & 0.15 & 545 & 0.06 & 0.14 & 2929 & 0.07 & 0.17 & 8608 & 0.04 & 0.09 \\
\hline$\Delta$ Balances Delinquent $(\%)$ & 442 & 0.04 & 0.09 & 545 & 0.04 & 0.10 & 2929 & 0.04 & 0.10 & 8608 & 0.02 & 0.06 \\
\hline$\Delta$ Median Balance & 445 & 8.03 & 478.72 & 555 & 340.60 & 3769.65 & 3006 & 13.64 & 572.87 & 8680 & 57.58 & 1191.32 \\
\hline \multicolumn{13}{|l|}{ Bank Cards } \\
\hline$\Delta$ Borrowers $(\%)$ & 445 & -0.10 & 0.11 & 555 & -0.10 & 0.12 & 3006 & -0.10 & 0.11 & 8680 & -0.08 & 0.09 \\
\hline$\Delta$ Borrowers Delinquent (\%) & 444 & -0.07 & 0.15 & 550 & -0.08 & 0.15 & 2981 & -0.08 & 0.18 & 8647 & -0.04 & 0.10 \\
\hline$\Delta$ Borrowers Severely Delinquent (\%) & 444 & -0.06 & 0.14 & 550 & -0.06 & 0.15 & 2981 & -0.07 & 0.18 & 8647 & -0.03 & 0.10 \\
\hline$\Delta$ Balances Delinquent $(\%)$ & 444 & -0.02 & 0.21 & 550 & -0.01 & 0.21 & 2981 & -0.01 & 0.24 & 8647 & 0.02 & 0.15 \\
\hline$\Delta$ Median Balance & 445 & -96.82 & 327.84 & 555 & -112.88 & 380.63 & 3006 & -67.92 & 275.61 & 8680 & -242.55 & 510.61 \\
\hline \multicolumn{13}{|l|}{ Mortgage Loans } \\
\hline$\Delta$ Borrowers $(\%)$ & 445 & 0.04 & 0.06 & 555 & 0.03 & 0.07 & 3006 & 0.03 & 0.06 & 8680 & 0.02 & 0.08 \\
\hline$\Delta$ Borrowers Delinquent (\%) & 381 & 0.04 & 0.20 & 481 & 0.04 & 0.21 & 2248 & 0.04 & 0.25 & 8295 & 0.03 & 0.13 \\
\hline$\Delta$ Borrowers Severely Delinquent (\%) & 381 & 0.03 & 0.13 & 481 & 0.03 & 0.15 & 2248 & 0.04 & 0.17 & 8295 & 0.03 & 0.09 \\
\hline$\Delta$ Balances Delinquent $(\%)$ & 381 & 0.05 & 0.21 & 481 & 0.05 & 0.23 & 2249 & 0.04 & 0.27 & 8295 & 0.04 & 0.15 \\
\hline$\Delta$ Median Balance & 445 & 49.13 & 1342.55 & 555 & 84.47 & 2261.48 & 3006 & 36.16 & 1478.66 & 8680 & -266.52 & 9788.33 \\
\hline \multicolumn{13}{|l|}{ Retail Loans } \\
\hline$\Delta$ Borrowers (\%) & 445 & -0.05 & 0.08 & 555 & -0.05 & 0.10 & 3006 & -0.05 & 0.09 & 8680 & -0.03 & 0.08 \\
\hline$\Delta$ Borrowers Delinquent (\%) & 434 & -0.13 & 0.20 & 543 & -0.12 & 0.19 & 2920 & -0.14 & 0.22 & 8598 & -0.08 & 0.14 \\
\hline$\Delta$ Borrowers Severely Delinquent (\%) & 434 & -0.13 & 0.19 & 543 & -0.12 & 0.19 & 2920 & -0.14 & 0.21 & 8598 & -0.08 & 0.13 \\
\hline$\Delta$ Balances Delinquent $(\%)$ & 435 & -0.17 & 0.28 & 543 & -0.15 & 0.26 & 2921 & -0.18 & 0.29 & 8598 & -0.11 & 0.22 \\
\hline$\Delta$ Median Balance & 445 & -0.15 & 16.19 & 555 & -0.77 & 34.45 & 3006 & -0.19 & 27.73 & 8680 & -0.23 & 16.94 \\
\hline
\end{tabular}

Notes: Weighted by number of individuals in the block group. Data sources: Federal Reserve Bank of New York Consumer Credit Panel/Equifax. 
Table A4. Effect of Texas Enterprise Zone Program on the Change in Aggregate Financial Outcomes: $\Delta(2006: Q 4-2002: Q 4)$

\begin{tabular}{|c|c|c|c|c|c|c|c|c|c|c|c|}
\hline & $\begin{array}{l}\text { Median Risk } \\
\text { Score }\end{array}$ & $\begin{array}{c}\text { Prime Risk } \\
\text { Score (Percent) }\end{array}$ & $\begin{array}{l}\text { Near Prime } \\
\text { Risk Score } \\
\text { (Percent) }\end{array}$ & $\begin{array}{l}\text { Sub-Prime Risk } \\
\text { Score (Percent) }\end{array}$ & $\begin{array}{c}\text { Chapter } 7 \\
\text { Bankruptcy } \\
\text { (Percent) }\end{array}$ & $\begin{array}{c}\text { Chapter } 13 \\
\text { Bankruptcy } \\
\text { (Percent) }\end{array}$ & $\begin{array}{c}\text { Median } \\
\text { Number of } \\
\text { Credit } \\
\text { Inquiries (Past } \\
3 \text { Months) }\end{array}$ & $\begin{array}{c}\text { Median } \\
\text { Number of } \\
\text { Credit } \\
\text { Inquiries (Past } \\
12 \text { Months) }\end{array}$ & $\begin{array}{c}\text { Median } \\
\text { Number of } \\
\text { New Accounts } \\
\text { (Past 6 } \\
\text { Months) }\end{array}$ & $\begin{array}{c}\text { Median } \\
\text { Number of } \\
\text { New Revolving } \\
\text { Accounts (Past } \\
6 \text { Months) }\end{array}$ & $\begin{array}{c}\text { Median } \\
\text { Number of } \\
\text { New Accounts } \\
\text { (Past } 12 \\
\text { Months) }\end{array}$ \\
\hline \multicolumn{12}{|c|}{ I. Bandwidth $=0.01$} \\
\hline \multirow[t]{2}{*}{ TX EZ (1 = Yes) } & -9.183 & $-0.053 *$ & 0.044 & 0.009 & -0.013 & 0.010 & 0.035 & 0.500 & -0.007 & -0.941 & -0.018 \\
\hline & (13.091) & $(0.028)$ & $(0.027)$ & $(0.037)$ & $(0.008)$ & $(0.006)$ & $(0.288)$ & $(0.542)$ & $(0.056)$ & (2.008) & $(0.250)$ \\
\hline $\mathrm{N}$ & 537 & 537 & 537 & 537 & 537 & 537 & 537 & 537 & 537 & 537 & 537 \\
\hline \multicolumn{12}{|c|}{ II. Bandwidth $=0.03$} \\
\hline \multirow[t]{2}{*}{ TX EZ (1 = Yes) } & 7.193 & -0.002 & -0.005 & 0.007 & -0.001 & $0.008 * * *$ & -0.412 & -0.233 & -0.008 & 0.447 & 0.011 \\
\hline & (6.339) & $(0.013)$ & $(0.012)$ & $(0.017)$ & $(0.005)$ & $(0.003)$ & (0.673) & $(0.687)$ & $(0.031)$ & (1.274) & $(0.154)$ \\
\hline $\mathrm{N}$ & 1465 & 1465 & 1465 & 1465 & 1465 & 1465 & 1465 & 1465 & 1465 & 1465 & 1465 \\
\hline \multicolumn{12}{|c|}{ III. Bandwidth = 0.05} \\
\hline \multirow[t]{2}{*}{ TX EZ (1 = Yes) } & 4.885 & 0.005 & -0.006 & 0.001 & 0.000 & $0.008 * * *$ & -0.087 & -0.061 & 0.006 & 0.358 & 0.098 \\
\hline & (4.410) & $(0.010)$ & $(0.010)$ & $(0.012)$ & $(0.004)$ & $(0.002)$ & $(0.435)$ & $(0.511)$ & $(0.022)$ & $(0.793)$ & (0.128) \\
\hline $\mathrm{N}$ & 2466 & 2466 & 2466 & 2466 & 2466 & 2466 & 2466 & 2466 & 2466 & 2466 & 2466 \\
\hline \multicolumn{12}{|c|}{ IV. Bandwidth $=0.10$} \\
\hline \multirow[t]{2}{*}{ TX EZ (1 = Yes) } & 2.595 & 0.004 & 0.002 & -0.005 & 0.002 & $0.005 * *$ & 0.633 & 0.605 & 0.002 & 0.631 & 0.024 \\
\hline & (4.379) & $(0.011)$ & $(0.009)$ & $(0.013)$ & $(0.002)$ & $(0.002)$ & $(0.393)$ & $(0.433)$ & $(0.018)$ & $(0.995)$ & $(0.089)$ \\
\hline $\mathrm{N}$ & 5029 & 5029 & 5029 & 5029 & 5029 & 5029 & 5029 & 5029 & 5029 & 5029 & 5029 \\
\hline
\end{tabular}

Notes: ${ }^{*} \mathrm{p}<0.10,{ }^{* *} \mathrm{p}<0.05,{ }^{* * *} \mathrm{p}<0.01$. Sample restricted to Census block groups a poverty rate within the listed bandwidth around 0.2 in 2000 . Estimation is by OLS, weighted by number of individuals in the block group. Covariates include all variables listed in Table A1 in the appendix. Standard errors are clustered at the county level. Data sources: Federal Reserve Bank of New

York Consumer Credit Panel/Equifax and 2000 Decennial Census. 
Table A5. Effect of Texas Enterprise Zone Program on the Change in Aggregate Financial Outcomes: $\Delta(2009:$ Q4-2002:Q4)

\begin{tabular}{|c|c|c|c|c|c|c|c|c|c|c|c|}
\hline & $\begin{array}{l}\text { Median Risk } \\
\text { Score }\end{array}$ & $\begin{array}{c}\text { Prime Risk } \\
\text { Score (Percent) }\end{array}$ & $\begin{array}{c}\text { Near Prime } \\
\text { Risk Score } \\
\text { (Percent) }\end{array}$ & $\begin{array}{l}\text { Sub-Prime Risk } \\
\text { Score (Percent) }\end{array}$ & $\begin{array}{c}\text { Chapter } 7 \\
\text { Bankruptcy } \\
\text { (Percent) }\end{array}$ & $\begin{array}{c}\text { Chapter } 13 \\
\text { Bankruptcy } \\
\text { (Percent) }\end{array}$ & $\begin{array}{c}\text { Median } \\
\text { Number of } \\
\text { Credit } \\
\text { Inquiries (Past } \\
3 \text { Months) }\end{array}$ & $\begin{array}{c}\text { Median } \\
\text { Number of } \\
\text { Credit } \\
\text { Inquiries (Past } \\
12 \text { Months) }\end{array}$ & $\begin{array}{c}\text { Median } \\
\text { Number of } \\
\text { New Accounts } \\
\text { (Past } 6 \\
\text { Months) }\end{array}$ & $\begin{array}{c}\text { Median } \\
\text { Number of } \\
\text { New Revolving } \\
\text { Accounts (Past } \\
6 \text { Months) }\end{array}$ & $\begin{array}{c}\text { Median } \\
\text { Number of } \\
\text { New Accounts } \\
\text { (Past } 12 \\
\text { Months) }\end{array}$ \\
\hline \multicolumn{12}{|c|}{ I. Bandwidth $=0.01$} \\
\hline \multirow[t]{2}{*}{ TX EZ (1 = Yes) } & -7.933 & $-0.133 *$ & 0.047 & 0.086 & -0.009 & $0.012 *$ & -0.633 & -0.056 & -0.040 & -0.623 & -0.174 \\
\hline & $(12.757)$ & $(0.068)$ & $(0.029)$ & $(0.054)$ & $(0.012)$ & $(0.007)$ & (1.619) & $(1.818)$ & $(0.034)$ & $(1.804)$ & $(0.176)$ \\
\hline $\mathrm{N}$ & 536 & 536 & 536 & 536 & 536 & 536 & 536 & 536 & 536 & 536 & 536 \\
\hline \multicolumn{12}{|c|}{ II. Bandwidth $=0.03$} \\
\hline \multirow[t]{2}{*}{ TX EZ (1 = Yes) } & 5.188 & -0.048 & 0.023 & 0.026 & 0.007 & $0.006 *$ & $-1.330 *$ & -1.160 & -0.173 & 1.585 & -0.218 \\
\hline & $(6.781)$ & $(0.036)$ & $(0.019)$ & $(0.028)$ & $(0.006)$ & $(0.003)$ & $(0.718)$ & $(0.774)$ & $(0.149)$ & (1.598) & $(0.222)$ \\
\hline $\mathrm{N}$ & 1463 & 1463 & 1463 & 1463 & 1463 & 1463 & 1463 & 1463 & 1463 & 1463 & 1463 \\
\hline \multicolumn{12}{|c|}{ III. Bandwidth $=0.05$} \\
\hline \multirow[t]{2}{*}{ TX EZ (1 = Yes) } & 2.675 & -0.032 & 0.011 & 0.021 & 0.005 & $0.007 * *$ & $-1.517 *$ & $-1.519 *$ & -0.009 & 0.771 & 0.000 \\
\hline & $(4.660)$ & $(0.025)$ & $(0.013)$ & $(0.020)$ & $(0.004)$ & $(0.003)$ & $(0.894)$ & $(0.877)$ & $(0.020)$ & $(0.844)$ & $(0.106)$ \\
\hline $\mathrm{N}$ & 2463 & 2463 & 2463 & 2463 & 2463 & 2463 & 2463 & 2463 & 2463 & 2463 & 2463 \\
\hline \multicolumn{12}{|c|}{ IV. Bandwidth $=0.10$} \\
\hline \multirow{2}{*}{ TX EZ (1 = Yes) } & 2.069 & -0.027 & $0.022 * * *$ & 0.005 & 0.004 & $0.005 * * *$ & -0.289 & -0.340 & -0.033 & -0.047 & -0.144 \\
\hline & (4.379) & $(0.017)$ & $(0.008)$ & $(0.017)$ & $(0.003)$ & $(0.002)$ & $(1.007)$ & $(0.991)$ & $(0.042)$ & $(0.859)$ & $(0.090)$ \\
\hline $\mathrm{N}$ & 5026 & 5026 & 5026 & 5026 & 5026 & 5026 & 5026 & 5026 & 5026 & 5026 & 5026 \\
\hline
\end{tabular}

Notes: ${ }^{*} \mathrm{p}<0.10,{ }^{* *} \mathrm{p}<0.05,{ }^{* * *} \mathrm{p}<0.01$. Sample restricted to Census block groups a poverty rate within the listed bandwidth around 0.2 in 2000 . Estimation is by OLS, weighted by number of individuals in the block group. Covariates include all variables listed in Table A1 in the appendix. Standard errors are clustered at the county level. Data sources: Federal Reserve Bank of New

York Consumer Credit Panel/Equifax and 2000 Decennial Census. 
Table A6. Effect of Texas Enterprise Zone Program on the Change in Aggregate Financial Outcomes: Auto Loans

\begin{tabular}{|c|c|c|c|c|c|c|c|c|c|c|}
\hline & \multicolumn{5}{|c|}{$\Delta(2006: Q 4-2002: Q 4)$} & \multicolumn{5}{|c|}{$\Delta(2009: Q 4-2002: Q 4)$} \\
\hline & $\begin{array}{c}\text { Borrowers } \\
\text { (Percent) }\end{array}$ & $\begin{array}{c}\text { Borrowers } \\
\text { Delinquent } \\
\text { (Percent) }\end{array}$ & $\begin{array}{l}\text { Borrowers } \\
\text { Severely } \\
\text { Delinquent } \\
\text { (Percent) }\end{array}$ & $\begin{array}{c}\text { Balance } \\
\text { Delinquent } \\
\text { (Percent) }\end{array}$ & $\begin{array}{l}\text { Median } \\
\text { Balance } \\
\text { (Dollars) }\end{array}$ & $\begin{array}{c}\text { Borrowers } \\
\text { (Percent) }\end{array}$ & $\begin{array}{c}\text { Borrowers } \\
\text { Delinquent } \\
\text { (Percent) }\end{array}$ & $\begin{array}{l}\text { Borrowers } \\
\text { Severely } \\
\text { Delinquent } \\
\text { (Percent) }\end{array}$ & $\begin{array}{c}\text { Balance } \\
\text { Delinquent } \\
\text { (Percent) }\end{array}$ & $\begin{array}{l}\text { Median } \\
\text { Balance } \\
\text { (Dollars) }\end{array}$ \\
\hline \multicolumn{11}{|c|}{ I. Bandwidth = 0.01} \\
\hline \multirow[t]{2}{*}{ TX EZ (1 = Yes) } & 0.003 & $0.083 * *$ & 0.012 & 0.029 & 16.31 & -0.054 & 0.051 & 0.036 & 0.024 & -6504.4 \\
\hline & $(0.025)$ & $(0.037)$ & $(0.028)$ & $(0.017)$ & $(51.41)$ & $(0.092)$ & $(0.057)$ & $(0.045)$ & $(0.039)$ & $(5168.4)$ \\
\hline $\mathrm{N}$ & 537 & 530 & 530 & 530 & 537 & 536 & 532 & 532 & 532 & 536 \\
\hline \multicolumn{11}{|c|}{ II. Bandwidth $=0.03$} \\
\hline \multirow[t]{2}{*}{ TX EZ (1 = Yes) } & -0.007 & $0.083 * * *$ & $0.037 *$ & $0.031 * *$ & 8.70 & -0.042 & 0.000 & 0.016 & -0.005 & -2866.3 \\
\hline & $(0.013)$ & $(0.025)$ & $(0.021)$ & $(0.015)$ & $(36.31)$ & $(0.045)$ & $(0.025)$ & $(0.018)$ & $(0.017)$ & (2591.0) \\
\hline $\mathrm{N}$ & 1465 & 1441 & 1441 & 1441 & 1465 & 1463 & 1440 & 1440 & 1440 & 1463 \\
\hline \multicolumn{11}{|c|}{ III. Bandwidth $=0.05$} \\
\hline \multirow[t]{2}{*}{ TX EZ (1 = Yes) } & -0.001 & $0.064 * * *$ & $0.046 * * *$ & $0.025 * *$ & -15.26 & -0.018 & -0.009 & 0.002 & -0.012 & -1921.7 \\
\hline & $(0.010)$ & $(0.022)$ & $(0.015)$ & $(0.011)$ & (18.77) & $(0.031)$ & $(0.019)$ & $(0.016)$ & $(0.013)$ & (1808.8) \\
\hline $\mathrm{N}$ & 2466 & 2435 & 2435 & 2435 & 2466 & 2463 & 2434 & 2434 & 2434 & 2463 \\
\hline \multicolumn{11}{|c|}{ IV. Bandwidth $=0.10$} \\
\hline \multirow[t]{2}{*}{ TX EZ (1 = Yes) } & 0.005 & $0.029 *$ & 0.018 & 0.011 & $-58.59 *$ & -0.003 & 0.004 & 0.009 & -0.001 & -967.29 \\
\hline & $(0.008)$ & $(0.015)$ & $(0.011)$ & $(0.008)$ & $(34.497)$ & $(0.019)$ & $(0.015)$ & $(0.013)$ & $(0.010)$ & $(936.80)$ \\
\hline $\mathrm{N}$ & 5029 & 4965 & 4965 & 4965 & 5029 & 5026 & 4963 & 4963 & 4963 & 5026 \\
\hline
\end{tabular}

Notes: ${ }^{*} \mathrm{p}<0.10,{ }^{* *} \mathrm{p}<0.05,{ }^{* * *} \mathrm{p}<0.01$. Sample restricted to Census block groups a poverty rate within the listed bandwidth around 0.2 in 2000 . Estimation is by OLS,

weighted by number of individuals in the block group. Covariates include all variables listed in Table A1 in the appendix. Standard errors are clustered at the county level. Data sources: Federal Reserve Bank of New York Consumer Credit Panel/Equifax and 2000 Decennial Census. 
Table A7. Effect of Texas Enterprise Zone Program on the Change in Aggregate Financial Outcomes: Bank Cards

\begin{tabular}{|c|c|c|c|c|c|c|c|c|c|c|}
\hline & \multicolumn{5}{|c|}{$\Delta(2006: Q 4-2002: Q 4)$} & \multicolumn{5}{|c|}{$\Delta(2009: Q 4-2002: Q 4)$} \\
\hline & $\begin{array}{c}\text { Borrowers } \\
\text { (Percent) }\end{array}$ & $\begin{array}{c}\text { Borrowers } \\
\text { Delinquent } \\
\text { (Percent) }\end{array}$ & $\begin{array}{l}\text { Borrowers } \\
\text { Severely } \\
\text { Delinquent } \\
\text { (Percent) }\end{array}$ & $\begin{array}{c}\text { Balance } \\
\text { Delinquent } \\
\text { (Percent) }\end{array}$ & $\begin{array}{l}\text { Median } \\
\text { Balance } \\
\text { (Dollars) }\end{array}$ & $\begin{array}{c}\text { Borrowers } \\
\text { (Percent) }\end{array}$ & $\begin{array}{c}\text { Borrowers } \\
\text { Delinquent } \\
\text { (Percent) }\end{array}$ & $\begin{array}{l}\text { Borrowers } \\
\text { Severely } \\
\text { Delinquent } \\
\text { (Percent) }\end{array}$ & $\begin{array}{c}\text { Balance } \\
\text { Delinquent } \\
\text { (Percent) }\end{array}$ & $\begin{array}{l}\text { Median } \\
\text { Balance } \\
\text { (Dollars) }\end{array}$ \\
\hline \multicolumn{11}{|c|}{ I. Bandwidth = 0.01} \\
\hline \multirow[t]{2}{*}{ TX EZ (1 = Yes) } & 0.009 & -0.016 & -0.027 & 0.003 & -28.94 & 0.052 & -0.015 & -0.022 & -0.001 & -6.22 \\
\hline & $(0.027)$ & $(0.041)$ & $(0.045)$ & $(0.080)$ & (108.04) & $(0.067)$ & $(0.055)$ & $(0.056)$ & $(0.062)$ & $(112.02)$ \\
\hline $\mathrm{N}$ & 537 & 536 & 536 & 536 & 537 & 536 & 534 & 534 & 534 & 536 \\
\hline \multicolumn{11}{|c|}{ II. Bandwidth $=\mathbf{0 . 0 3}$} \\
\hline \multirow[t]{2}{*}{ TX EZ (1 = Yes) } & 0.014 & 0.023 & 0.009 & 0.037 & 49.93 & 0.028 & 0.003 & -0.001 & 0.018 & 37.38 \\
\hline & $(0.019)$ & $(0.021)$ & $(0.023)$ & $(0.033)$ & (77.83) & $(0.032)$ & $(0.025)$ & $(0.030)$ & $(0.036)$ & (73.11) \\
\hline $\mathrm{N}$ & 1465 & 1458 & 1458 & 1458 & 1465 & 1463 & 1453 & 1453 & 1453 & 1463 \\
\hline \multicolumn{11}{|c|}{ III. Bandwidth $=0.05$} \\
\hline \multirow[t]{2}{*}{ TX EZ (1 = Yes) } & 0.004 & $0.030 * *$ & 0.018 & $0.044 * *$ & 8.43 & 0.013 & 0.010 & 0.005 & 0.014 & 1.60 \\
\hline & $(0.009)$ & $(0.014)$ & $(0.013)$ & $(0.020)$ & (38.06) & $(0.023)$ & $(0.017)$ & $(0.019)$ & $(0.025)$ & (51.97) \\
\hline $\mathrm{N}$ & 2466 & 2457 & 2457 & 2457 & 2466 & 2463 & 2450 & 2450 & 2450 & 2463 \\
\hline \multicolumn{11}{|c|}{ IV. Bandwidth $=0.10$} \\
\hline \multirow[t]{2}{*}{ TX EZ (1 = Yes) } & 0.000 & 0.005 & -0.006 & 0.001 & 13.75 & -0.002 & -0.002 & -0.009 & -0.017 & 3.62 \\
\hline & $(0.010)$ & $(0.013)$ & $(0.013)$ & $(0.022)$ & (32.548) & $(0.014)$ & $(0.012)$ & $(0.011)$ & $(0.018)$ & $(48.66)$ \\
\hline $\mathrm{N}$ & 5029 & 5012 & 5012 & 5012 & 5029 & 5026 & 5004 & 5004 & 5004 & 5026 \\
\hline
\end{tabular}

Notes: ${ }^{*} \mathrm{p}<0.10,{ }^{* *} \mathrm{p}<0.05,{ }^{* * *} \mathrm{p}<0.01$. Sample restricted to Census block groups a poverty rate within the listed bandwidth around 0.2 in 2000 . Estimation is by OLS,

weighted by number of individuals in the block group. Covariates include all variables listed in Table A1 in the appendix. Standard errors are clustered at the county level. Data sources: Federal Reserve Bank of New York Consumer Credit Panel/Equifax and 2000 Decennial Census. 
Table A8. Effect of Texas Enterprise Zone Program on the Change in Aggregate Financial Outcomes: Mortgage Loans

\begin{tabular}{|c|c|c|c|c|c|c|c|c|c|c|}
\hline & \multicolumn{5}{|c|}{$\Delta(2006: Q 4-2002: Q 4)$} & \multicolumn{5}{|c|}{$\Delta(2009: Q 4-2002: Q 4)$} \\
\hline & $\begin{array}{c}\text { Borrowers } \\
\text { (Percent) }\end{array}$ & $\begin{array}{c}\text { Borrowers } \\
\text { Delinquent } \\
\text { (Percent) }\end{array}$ & $\begin{array}{l}\text { Borrowers } \\
\text { Severely } \\
\text { Delinquent } \\
\text { (Percent) }\end{array}$ & $\begin{array}{c}\text { Balance } \\
\text { Delinquent } \\
\text { (Percent) }\end{array}$ & $\begin{array}{l}\text { Median } \\
\text { Balance } \\
\text { (Dollars) }\end{array}$ & $\begin{array}{c}\text { Borrowers } \\
\text { (Percent) }\end{array}$ & $\begin{array}{c}\text { Borrowers } \\
\text { Delinquent } \\
\text { (Percent) }\end{array}$ & $\begin{array}{l}\text { Borrowers } \\
\text { Severely } \\
\text { Delinquent } \\
\text { (Percent) }\end{array}$ & $\begin{array}{c}\text { Balance } \\
\text { Delinquent } \\
\text { (Percent) }\end{array}$ & $\begin{array}{l}\text { Median } \\
\text { Balance } \\
\text { (Dollars) }\end{array}$ \\
\hline \multicolumn{11}{|c|}{ I. Bandwidth $=0.01$} \\
\hline \multirow[t]{2}{*}{ TX EZ (1 = Yes) } & -0.016 & 0.014 & -0.019 & 0.028 & -123.41 & 0.034 & 0.106 & 0.009 & 0.095 & 44.8 \\
\hline & $(0.019)$ & $(0.049)$ & $(0.025)$ & $(0.058)$ & $(416.36)$ & $(0.025)$ & $(0.065)$ & $(0.044)$ & $(0.065)$ & $(487.5)$ \\
\hline $\mathrm{N}$ & 537 & 467 & 467 & 467 & 537 & 536 & 469 & 469 & 469 & 536 \\
\hline \multicolumn{11}{|c|}{ II. Bandwidth $=0.03$} \\
\hline \multirow[t]{2}{*}{ TX EZ (1 = Yes) } & 0.004 & 0.042 & $0.045 * *$ & $0.076 *$ & 66.87 & 0.002 & 0.043 & 0.023 & 0.054 & -22.8 \\
\hline & $(0.012)$ & $(0.035)$ & (0.019) & $(0.045)$ & (65.93) & $(0.015)$ & $(0.049)$ & $(0.028)$ & $(0.052)$ & (73.9) \\
\hline $\mathrm{N}$ & 1465 & 1257 & 1257 & 1257 & 1465 & 1463 & 1257 & 1257 & 1257 & 1463 \\
\hline \multicolumn{11}{|c|}{ III. Bandwidth $=0.05$} \\
\hline \multirow[t]{2}{*}{ TX EZ (1 = Yes) } & 0.007 & 0.010 & $0.033 * * *$ & 0.036 & -127.73 & $0.018 * *$ & 0.040 & 0.011 & 0.041 & -119.7 \\
\hline & $(0.007)$ & $(0.031)$ & $(0.012)$ & $(0.032)$ & (107.93) & $(0.009)$ & $(0.041)$ & $(0.022)$ & $(0.039)$ & $(159.0)$ \\
\hline $\mathrm{N}$ & 2466 & 2132 & 2132 & 2132 & 2466 & 2463 & 2144 & 2144 & 2144 & 2463 \\
\hline \multicolumn{11}{|c|}{ IV. Bandwidth $=0.10$} \\
\hline \multirow[t]{2}{*}{ TX EZ (1 = Yes) } & 0.004 & -0.011 & 0.013 & 0.002 & -89.22 & $0.016 *$ & 0.007 & 0.000 & 0.001 & 11.81 \\
\hline & $(0.006)$ & $(0.018)$ & $(0.009)$ & $(0.019)$ & (197.4) & $(0.009)$ & $(0.023)$ & $(0.012)$ & $(0.022)$ & $(286.36)$ \\
\hline $\mathrm{N}$ & 5029 & 4419 & 4419 & 4420 & 5029 & 5026 & 4439 & 4439 & 4439 & 5026 \\
\hline
\end{tabular}

Notes: ${ }^{*} \mathrm{p}<0.10,{ }^{* *} \mathrm{p}<0.05,{ }^{* * *} \mathrm{p}<0.01$. Sample restricted to Census block groups a poverty rate within the listed bandwidth around 0.2 in 2000 . Estimation is by OLS,

weighted by number of individuals in the block group. Covariates include all variables listed in Table A1 in the appendix. Standard errors are clustered at the county level. Data sources: Federal Reserve Bank of New York Consumer Credit Panel/Equifax and 2000 Decennial Census. 
Table A9. Effect of Texas Enterprise Zone Program on the Change in Aggregate Financial Outcomes: Retail Loans

\begin{tabular}{|c|c|c|c|c|c|c|c|c|c|c|}
\hline & \multicolumn{5}{|c|}{$\Delta(2006: Q 4-2002: Q 4)$} & \multicolumn{5}{|c|}{$\Delta(2009: Q 4-2002: Q 4)$} \\
\hline & $\begin{array}{c}\text { Borrowers } \\
\text { (Percent) }\end{array}$ & $\begin{array}{c}\text { Borrowers } \\
\text { Delinquent } \\
\text { (Percent) }\end{array}$ & $\begin{array}{l}\text { Borrowers } \\
\text { Severely } \\
\text { Delinquent } \\
\text { (Percent) }\end{array}$ & $\begin{array}{c}\text { Balance } \\
\text { Delinquent } \\
\text { (Percent) }\end{array}$ & $\begin{array}{l}\text { Median } \\
\text { Balance } \\
\text { (Dollars) }\end{array}$ & $\begin{array}{c}\text { Borrowers } \\
\text { (Percent) }\end{array}$ & $\begin{array}{c}\text { Borrowers } \\
\text { Delinquent } \\
\text { (Percent) }\end{array}$ & $\begin{array}{l}\text { Borrowers } \\
\text { Severely } \\
\text { Delinquent } \\
\text { (Percent) }\end{array}$ & $\begin{array}{c}\text { Balance } \\
\text { Delinquent } \\
\text { (Percent) }\end{array}$ & $\begin{array}{c}\text { Median } \\
\text { Balance } \\
\text { (Dollars) }\end{array}$ \\
\hline \multicolumn{11}{|c|}{ I. Bandwidth $=0.01$} \\
\hline \multirow[t]{2}{*}{ TX EZ (1 = Yes) } & 0.011 & -0.033 & -0.001 & 0.041 & 0.176 & 0.037 & -0.127 & -0.086 & -0.066 & -0.853 \\
\hline & $(0.028)$ & $(0.087)$ & $(0.073)$ & $(0.114)$ & (1.266) & $(0.051)$ & $(0.078)$ & $(0.069)$ & $(0.090)$ & (1.535) \\
\hline $\mathrm{N}$ & 537 & 529 & 529 & 529 & 537 & 536 & 524 & 524 & 524 & 536 \\
\hline \multicolumn{11}{|c|}{ II. Bandwidth $=0.03$} \\
\hline \multirow[t]{2}{*}{ TX EZ (1 = Yes) } & 0.000 & 0.007 & 0.004 & -0.011 & 1.957 & 0.018 & -0.048 & $-0.077 * * *$ & $-0.089 *$ & 2.836 \\
\hline & $(0.013)$ & $(0.041)$ & $(0.037)$ & $(0.048)$ & $(1.762)$ & $(0.023)$ & $(0.032)$ & $(0.029)$ & $(0.052)$ & (1.853) \\
\hline $\mathrm{N}$ & 1465 & 1441 & 1441 & 1441 & 1465 & 1463 & 1432 & 1432 & 1433 & 1463 \\
\hline \multicolumn{11}{|c|}{ III. Bandwidth $=0.05$} \\
\hline \multirow[t]{2}{*}{ TX EZ (1 = Yes) } & -0.005 & 0.010 & 0.020 & 0.022 & 0.488 & 0.017 & $-0.076 * * *$ & $-0.076 * * *$ & $-0.087 * *$ & 2.181 \\
\hline & $(0.012)$ & $(0.031)$ & $(0.029)$ & $(0.045)$ & $(1.316)$ & $(0.015)$ & $(0.023)$ & $(0.021)$ & $(0.038)$ & $(1.470)$ \\
\hline $\mathrm{N}$ & 2466 & 2424 & 2424 & 2424 & 2466 & 2463 & 2418 & 2418 & 2419 & 2463 \\
\hline \multicolumn{11}{|c|}{ IV. Bandwidth $=0.10$} \\
\hline \multirow[t]{2}{*}{ TX EZ (1 = Yes) } & -0.008 & 0.007 & 0.011 & -0.008 & -0.112 & 0.002 & $-0.035 *$ & -0.033 & -0.050 & 0.250 \\
\hline & $(0.008)$ & $(0.015)$ & $(0.014)$ & $(0.032)$ & $(1.162)$ & $(0.011)$ & $(0.021)$ & $(0.020)$ & $(0.032)$ & $(1.237)$ \\
\hline $\mathrm{N}$ & 5029 & 4950 & 4950 & 4950 & 5029 & 5026 & 4940 & 4940 & 4941 & 5026 \\
\hline
\end{tabular}

Notes: ${ }^{*} \mathrm{p}<0.10,{ }^{* *} \mathrm{p}<0.05,{ }^{* * *} \mathrm{p}<0.01$. Sample restricted to Census block groups a poverty rate within the listed bandwidth around 0.2 in 2000 . Estimation is by OLS,

weighted by number of individuals in the block group. Covariates include all variables listed in Table A1 in the appendix. Standard errors are clustered at the county level. Data sources: Federal Reserve Bank of New York Consumer Credit Panel/Equifax and 2000 Decennial Census. 
Table A10. Effect of Texas Enterprise Zone Program on the Change in Aggregate Financial Outcomes: Placebo Test $($ Cut-off $=0.175)$

\begin{tabular}{|c|c|c|c|c|c|c|c|c|c|c|c|}
\hline & $\begin{array}{c}\text { Median Risk } \\
\text { Score }\end{array}$ & $\begin{array}{c}\text { Prime Risk } \\
\text { Score (Percent) }\end{array}$ & $\begin{array}{c}\text { Near Prime } \\
\text { Risk Score } \\
\text { (Percent) }\end{array}$ & $\begin{array}{l}\text { Sub-Prime Risk } \\
\text { Score (Percent) }\end{array}$ & $\begin{array}{c}\text { Chapter } 7 \\
\text { Bankruptcy } \\
\text { (Percent) }\end{array}$ & $\begin{array}{c}\text { Chapter } 13 \\
\text { Bankruptcy } \\
\text { (Percent) }\end{array}$ & $\begin{array}{c}\text { Median } \\
\text { Number of } \\
\text { Credit } \\
\text { Inquiries (Past } \\
3 \text { Months) }\end{array}$ & $\begin{array}{c}\text { Median } \\
\text { Number of } \\
\text { Credit } \\
\text { Inquiries (Past } \\
12 \text { Months) }\end{array}$ & $\begin{array}{c}\text { Median } \\
\text { Number of } \\
\text { New Accounts } \\
\text { (Past } 6 \\
\text { Months) }\end{array}$ & $\begin{array}{c}\text { Median } \\
\text { Number of } \\
\text { New Revolving } \\
\text { Accounts (Past } \\
6 \text { Months) }\end{array}$ & $\begin{array}{c}\text { Median } \\
\text { Number of } \\
\text { New Accounts } \\
\text { (Past 12 } \\
\text { Months) }\end{array}$ \\
\hline \multicolumn{12}{|c|}{ I. $\Delta(2006: Q 4-2002: Q 4)$} \\
\hline TX EZ $(1=$ Yes $)$ & $\begin{array}{r}-6.548 \\
(7.4)\end{array}$ & $\begin{array}{r}0.011 \\
(0.019)\end{array}$ & $\begin{array}{l}-0.028 * \\
(0.016)\end{array}$ & $\begin{array}{r}0.017 \\
(0.024)\end{array}$ & $\begin{array}{r}-0.005 \\
(0.007)\end{array}$ & $\begin{array}{r}0.003 \\
(0.005)\end{array}$ & $\begin{array}{r}1.281 \\
(1.156)\end{array}$ & $\begin{array}{r}1.622 \\
(1.171)\end{array}$ & $\begin{array}{r}0.011 \\
(0.048)\end{array}$ & $\begin{array}{r}-0.818 \\
(0.956)\end{array}$ & $\begin{array}{r}0.041 \\
(0.192)\end{array}$ \\
\hline $\begin{array}{l}\mathrm{N} \\
\text { II. } \Delta(2009: \mathrm{Q} 4-20\end{array}$ & 1154 & 1154 & 1154 & 1154 & 1154 & 1154 & 1154 & 1154 & 1154 & 1154 & 1154 \\
\hline TX EZ (1 = Yes) & $\begin{array}{c}-14.881 * \\
(7.8)\end{array}$ & $\begin{array}{r}-0.033 \\
(0.027)\end{array}$ & $\begin{array}{r}0.005 \\
(0.023)\end{array}$ & $\begin{array}{r}0.028 \\
(0.024)\end{array}$ & $\begin{array}{r}-0.004 \\
(0.009)\end{array}$ & $\begin{array}{r}0.000 \\
(0.005)\end{array}$ & $\begin{array}{r}0.047 \\
(1.533)\end{array}$ & $\begin{array}{c}-0.372 \\
(1.510)\end{array}$ & $\begin{array}{r}0.028 \\
(0.043)\end{array}$ & $\begin{array}{r}-1.180 \\
(1.504)\end{array}$ & $\begin{array}{r}0.066 \\
(0.156)\end{array}$ \\
\hline $\mathrm{N}$ & 1154 & 1154 & 1154 & 1154 & 1154 & 1154 & 1154 & 1154 & 1154 & 1154 & 1154 \\
\hline
\end{tabular}

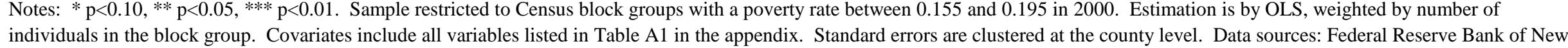

York Consumer Credit Panel/Equifax and 2000 Decennial Census. 
Table A11. Effect of Texas Enterprise Zone Program on the Change in Aggregate Financial Outcomes by Type: Placebo Test (Cut-off = 0.175)

\begin{tabular}{|c|c|c|c|c|c|c|c|c|c|c|}
\hline & \multicolumn{5}{|c|}{$\Delta(2006: \mathrm{Q} 4-2002: Q 4)$} & \multicolumn{5}{|c|}{$\Delta(2009: \mathrm{Q} 4-2002: Q 4)$} \\
\hline & $\begin{array}{c}\text { Borrowers } \\
\text { (Percent) }\end{array}$ & $\begin{array}{c}\text { Borrowers } \\
\text { Delinquent } \\
\text { (Percent) }\end{array}$ & $\begin{array}{c}\text { Borrowers } \\
\text { Severely } \\
\text { Delinquent } \\
\text { (Percent) }\end{array}$ & $\begin{array}{c}\text { Balance } \\
\text { Delinquent } \\
\text { (Percent) }\end{array}$ & $\begin{array}{c}\text { Median } \\
\text { Balance } \\
\text { (Dollars) }\end{array}$ & $\begin{array}{c}\text { Borrowers } \\
\text { (Percent) }\end{array}$ & $\begin{array}{c}\text { Borrowers } \\
\text { Delinquent } \\
\text { (Percent) }\end{array}$ & $\begin{array}{c}\text { Borrowers } \\
\text { Severely } \\
\text { Delinquent } \\
\text { (Percent) }\end{array}$ & $\begin{array}{c}\text { Balance } \\
\text { Delinquent } \\
\text { (Percent) }\end{array}$ & $\begin{array}{l}\text { Median } \\
\text { Balance } \\
\text { (Dollars) }\end{array}$ \\
\hline \multicolumn{11}{|l|}{ I. Auto Loans } \\
\hline \multirow[t]{2}{*}{ TX EZ $(1=$ Yes $)$} & $0.043 *$ & -0.035 & -0.025 & -0.015 & 9.523 & 0.017 & -0.013 & 0.012 & 0.000 & -95.7 \\
\hline & $(0.024)$ & $(0.029)$ & $(0.024)$ & $(0.015)$ & $(50.319)$ & $(0.028)$ & $(0.030)$ & $(0.025)$ & $(0.020)$ & $(106.0)$ \\
\hline $\mathrm{N}$ & 1154 & 1137 & 1137 & 1137 & 1154 & 1154 & 1136 & 1136 & 1136 & 1154 \\
\hline \multicolumn{11}{|l|}{ II. Bank Cards } \\
\hline \multirow[t]{2}{*}{ TX EZ (1 = Yes) } & 0.016 & 0.033 & 0.040 & 0.003 & $121.52 *$ & 0.002 & 0.044 & 0.039 & -0.028 & 9.30 \\
\hline & $(0.018)$ & $(0.034)$ & $(0.028)$ & $(0.031)$ & $(63.96)$ & $(0.023)$ & $(0.035)$ & $(0.029)$ & $(0.036)$ & (49.77) \\
\hline $\mathrm{N}$ & 1154 & 1148 & 1148 & 1148 & 1154 & 1154 & 1145 & 1145 & 1145 & 1154 \\
\hline \multicolumn{11}{|c|}{ III. Mortgage Loans } \\
\hline \multirow[t]{2}{*}{ TX EZ (1 = Yes) } & 0.003 & $0.066 *$ & 0.033 & $0.089 * *$ & 292.99 & -0.009 & 0.038 & 0.033 & 0.016 & 617.58 \\
\hline & $(0.019)$ & $(0.037)$ & $(0.023)$ & $(0.044)$ & (396.31) & $(0.020)$ & $(0.034)$ & $(0.026)$ & $(0.042)$ & (654.44) \\
\hline $\mathrm{N}$ & 1154 & 1020 & 1020 & 1020 & 1154 & 1154 & 1028 & 1028 & 1028 & 1154 \\
\hline \multicolumn{11}{|l|}{ IV. Retail Loans } \\
\hline \multirow[t]{2}{*}{ TX EZ (1 = Yes) } & $0.051 *$ & 0.014 & 0.015 & 0.055 & 1.617 & 0.030 & 0.067 & 0.051 & $0.146 * *$ & -0.455 \\
\hline & $(0.029)$ & $(0.045)$ & $(0.041)$ & $(0.056)$ & (2.235) & $(0.023)$ & $(0.046)$ & $(0.039)$ & $(0.064)$ & $(3.12)$ \\
\hline $\mathrm{N}$ & 1154 & 1137 & 1137 & 1137 & 1154 & 1154 & 1131 & 1131 & 1131 & 1154 \\
\hline
\end{tabular}

Notes: ${ }^{*} \mathrm{p}<0.10,{ }^{* *} \mathrm{p}<0.05,{ }^{* * *} \mathrm{p}<0.01$. Sample restricted to Census block groups with a poverty rate between 0.155 and 0.195 in 2000 . Estimation is by OLS, weighted by number of individuals in the block group. Covariates include all variables listed in Table A1 in the appendix. Standard errors are clustered at the county level. Data sources: Federal Reserve Bank of New York Consumer Credit Panel/Equifax and 2000 Decennial Census. 
Table A12. Effect of Texas Enterprise Zone Program on the Change in Aggregate Financial Outcomes: Placebo Test $($ Cut-off $=0.225)$

\begin{tabular}{|c|c|c|c|c|c|c|c|c|c|c|c|}
\hline & $\begin{array}{c}\text { Median Risk } \\
\text { Score }\end{array}$ & $\begin{array}{c}\text { Prime Risk } \\
\text { Score (Percent) }\end{array}$ & $\begin{array}{c}\text { Near Prime } \\
\text { Risk Score } \\
\text { (Percent) }\end{array}$ & $\begin{array}{l}\text { Sub-Prime Risk } \\
\text { Score (Percent) }\end{array}$ & $\begin{array}{c}\text { Chapter } 7 \\
\text { Bankruptcy } \\
\text { (Percent) }\end{array}$ & $\begin{array}{c}\text { Chapter } 13 \\
\text { Bankruptcy } \\
\text { (Percent) }\end{array}$ & $\begin{array}{c}\text { Median } \\
\text { Number of } \\
\text { Credit } \\
\text { Inquiries (Past } \\
3 \text { Months) }\end{array}$ & $\begin{array}{c}\text { Median } \\
\text { Number of } \\
\text { Credit } \\
\text { Inquiries (Past } \\
12 \text { Months) }\end{array}$ & $\begin{array}{c}\text { Median } \\
\text { Number of } \\
\text { New Accounts } \\
\text { (Past 6 } \\
\text { Months) }\end{array}$ & $\begin{array}{c}\text { Median } \\
\text { Number of } \\
\text { New Revolving } \\
\text { Accounts (Past } \\
6 \text { Months) }\end{array}$ & $\begin{array}{c}\text { Median } \\
\text { Number of } \\
\text { New Accounts } \\
\text { (Past 12 } \\
\text { Months) }\end{array}$ \\
\hline \multicolumn{12}{|c|}{ I. $\Delta(2006: Q 4-2002: Q 4)$} \\
\hline \multirow[t]{2}{*}{ TX EZ (1 = Yes) } & -0.527 & 0.004 & 0.007 & -0.011 & $0.016 * *$ & -0.008 & 0.258 & 0.309 & 0.066 & 0.179 & 0.312 \\
\hline & (12.577) & $(0.026)$ & $(0.028)$ & $(0.043)$ & $(0.007)$ & $(0.006)$ & $(0.787)$ & $(0.779)$ & $(0.059)$ & (1.086) & $(0.224)$ \\
\hline $\mathrm{N}$ & 770 & 770 & 770 & 770 & 770 & 770 & 770 & 770 & 770 & 770 & 770 \\
\hline \multicolumn{12}{|c|}{ II. $\Delta(2009: \mathrm{Q4-2002:Q4)}$} \\
\hline \multirow[t]{2}{*}{ TX EZ (1 = Yes) } & 3.419 & 0.004 & 0.006 & -0.010 & 0.010 & -0.012 & 0.319 & 0.270 & 0.162 & -2.352 & 0.172 \\
\hline & $(7.820)$ & $(0.026)$ & $(0.02)$ & $(0.027)$ & $(0.008)$ & $(0.007)$ & $(1.023)$ & $(1.022)$ & $(0.143)$ & (3.129) & $(0.182)$ \\
\hline $\mathrm{N}$ & 769 & 769 & 769 & 769 & 769 & 769 & 769 & 769 & 769 & 769 & 769 \\
\hline
\end{tabular}


Table A13. Effect of Texas Enterprise Zone Program on the Change in Aggregate Financial Outcomes by Type: Placebo Test (Cut-off = 0.225)

\begin{tabular}{|c|c|c|c|c|c|c|c|c|c|c|}
\hline & \multicolumn{5}{|c|}{$\Delta(2006: \mathrm{Q} 4-2002: \mathrm{Q} 4)$} & \multicolumn{5}{|c|}{$\Delta(2009: \mathrm{Q} 4-2002: Q 4)$} \\
\hline & $\begin{array}{c}\text { Borrowers } \\
\text { (Percent) }\end{array}$ & $\begin{array}{c}\text { Borrowers } \\
\text { Delinquent } \\
\text { (Percent) }\end{array}$ & $\begin{array}{c}\text { Borrowers } \\
\text { Severely } \\
\text { Delinquent } \\
\text { (Percent) }\end{array}$ & $\begin{array}{c}\text { Balance } \\
\text { Delinquent } \\
\text { (Percent) }\end{array}$ & $\begin{array}{l}\text { Median } \\
\text { Balance } \\
\text { (Dollars) }\end{array}$ & $\begin{array}{c}\text { Borrowers } \\
\text { (Percent) }\end{array}$ & $\begin{array}{c}\text { Borrowers } \\
\text { Delinquent } \\
\text { (Percent) }\end{array}$ & $\begin{array}{l}\text { Borrowers } \\
\text { Severely } \\
\text { Delinquent } \\
\text { (Percent) }\end{array}$ & $\begin{array}{c}\text { Balance } \\
\text { Delinquent } \\
\text { (Percent) }\end{array}$ & $\begin{array}{l}\text { Median } \\
\text { Balance } \\
\text { (Dollars) }\end{array}$ \\
\hline \multicolumn{11}{|l|}{ I. Auto Loans } \\
\hline \multirow[t]{2}{*}{ TX EZ (1 = Yes) } & 0.001 & -0.011 & -0.018 & 0.017 & $160.152 * *$ & $0.045 * *$ & 0.012 & 0.021 & -0.014 & 168.4 \\
\hline & $(0.022)$ & $(0.043)$ & $(0.027)$ & $(0.015)$ & (79.247) & $(0.019)$ & $(0.048)$ & $(0.053)$ & $(0.019)$ & (121.8) \\
\hline $\mathrm{N}$ & 770 & 765 & 765 & 765 & 770 & 769 & 762 & 762 & 762 & 769 \\
\hline \multicolumn{11}{|l|}{ II. Bank Cards } \\
\hline \multirow[t]{2}{*}{ TX EZ (1 = Yes) } & $0.061 *$ & 0.032 & 0.026 & 0.061 & 25.30 & 0.056 & -0.004 & 0.014 & -0.037 & 5.69 \\
\hline & $(0.033)$ & $(0.033)$ & $(0.034)$ & $(0.052)$ & $(68.70)$ & $(0.051)$ & $(0.033)$ & $(0.039)$ & $(0.062)$ & (69.17) \\
\hline $\mathrm{N}$ & 770 & 769 & 769 & 769 & 770 & 769 & 768 & 768 & 768 & 769 \\
\hline \multicolumn{11}{|c|}{ III. Mortgage Loans } \\
\hline \multirow[t]{2}{*}{$\operatorname{TX} \operatorname{EZ}(1=$ Yes $)$} & -0.013 & $-0.098 *$ & -0.055 & -0.024 & 420.32 & $-0.039 *$ & -0.051 & 0.024 & -0.025 & 22.83 \\
\hline & $(0.015)$ & $(0.059)$ & $(0.050)$ & $(0.065)$ & (306.14) & $(0.020)$ & $(0.059)$ & $(0.039)$ & $(0.059)$ & (219.09) \\
\hline $\mathrm{N}$ & 770 & 638 & 638 & 638 & 770 & 769 & 641 & 641 & 641 & 769 \\
\hline \multicolumn{11}{|l|}{ IV. Retail Loans } \\
\hline \multirow[t]{2}{*}{ TX EZ (1 = Yes) } & 0.000 & -0.005 & -0.012 & 0.029 & -0.876 & -0.032 & 0.031 & 0.022 & -0.019 & 0.482 \\
\hline & $(0.017)$ & $(0.064)$ & $(0.062)$ & $(0.072)$ & $(1.234)$ & $(0.021)$ & $(0.056)$ & $(0.059)$ & $(0.061)$ & $(0.79)$ \\
\hline $\mathrm{N}$ & 770 & 753 & 753 & 753 & 770 & 769 & 755 & 755 & 756 & 769 \\
\hline
\end{tabular}

Notes: ${ }^{*} \mathrm{p}<0.10,{ }^{* *} \mathrm{p}<0.05,{ }^{* * *} \mathrm{p}<0.01$. Sample restricted to Census block groups with a poverty rate between 0.205 and 0.245 in 2000 . Estimation is by OLS, weighted by number of individuals in the block group. Covariates include all variables listed in Table A1 in the appendix. Standard errors are clustered at the county level. Data sources: Federal Reserve Bank of New York Consumer Credit Panel/Equifax and 2000 Decennial Census. 